\title{
Proposta de sequência tecnocultural da Serra da Capivara (Piauí) do Pleistoceno final ao Holoceno recente
}

\author{
Marina Pagli, Lívia de Oliveira e Lucas ${ }^{\star \star}$, Antoine Lourdeau***
}

Palavras-chave: Tecnologia lítica; Serra da Capivara; Pré-história do Brasil.

Keywords: Lithic technology; Serra da Capivara; Prehistory of Brazil.
Resumo: O potencial arqueológico excepcional da região da Serra da Capivara, no Piauí, já foi demonstrado em numerosas publicações, principalmente enfocadas nas representações rupestres dos abrigos (as “tocas") e nas ocupações pleistocênicas, entre as mais antigas da América. Propomos aqui outra abordagem da pré-história da área, com uma apresentação das características e das mudanças dos sistemas técnicos ao longo da sequência de ocupação, do Pleistoceno final ao Holoceno recente. Baseamonos na análise direta dos vestígios líticos de três sítios (Toca do João Leite, Toca da Ema do Sítio do Brás, Toca do Baixão da Ana Maria) e nos dados acessíveis na bibliografia sobre outros sítios. A dúzia de sítios arqueológicos considerados nesse estudo abrange todo o período de ocupação da Serra da Capivara durante a pré-história. Podemos, assim, propor um novo olhar sobre a sequência técnica regional, que se divide em quatro grandes momentos.

Abstract: The great archaeological potential of the Serra da Capivara region, State of Piauí, Brazil, has already been demonstrated in many publications, mainly about the rock art in rockshelters (the "tocas") and the Pleistocene settlements, among the earliest ones in America. We propose here another approach to prehistory of this area, introducing the characteristics of the technical systems and their changes along the archaeological sequence, from latest Pleistocene to late Holocene. We based on the direct analyses of lithic remains from three sites (Toca do João Leite, Toca da Ema do Brás, Toca do Baixão da Ana Maria) and on data available in publications on other sites. The dozen archaeological sites taken into account in this study cover all of the prehistoric settlement period in the Serra da Capivara region. Hence, we propose new insight on the regional technical sequence, which can be divided in four main periods.

Recebido em: 3 de maio de 2016. Aprovado em: 12 de julho de 2016.
A região da Serra da Capivara, no Sudeste do Piauí, é bem conhecida na literatura pelas centenas de abrigos com pinturas rupestres que se encontram ao longo de seus paredões areníticos (GUIDON, 1991; PESSIS, 2003), assim como pela questão do primeiro povoamento das Américas, com o famoso sítio de Pedra Furada (PARENTI, 2001)². Menos conhecidos são os numerosos sítios arqueológicos escavados na área pela Fundação Museu do Homem Americano (FUMDHAM), sob direção de Niède Guidon, com cronologia ininterrompida do Pleistoceno final ao Holoceno recente (GUIDON; BUCO; IGNÁCIO, 2007; GUIDON; PESSIS;
MARTIN, 2009, entre outros) ${ }^{2}$ (Figura 1). Dentro deles, milhares de vestígios de pedra lascada foram encontrados, os quais permitem abordar a diacronia das ocupações humanas da Serra da Capivara ao longo da Pré-história, revelando especificidades técnicas, perdurações, evoluções, mudanças ou rupturas. No presente artigo, apresentamos o estudo direto de três sítios inéditos (Toca do João Leite, Toca da Ema do Sítio do Brás I, Toca do Baixão da Ana Maria) associado a uma revisão bibliográfica dos dados referentes às produções líticas pré-históricas na Serra da Capivara, no intuito de propor uma sequência tecnocultural regional.

\footnotetext{
*Université Paris Ouest Nanterre La Défense/França. E-mail: marina.pagli@gmail.com.

** Universidade Federal do Vale do São Francisco (UNIVASF) e Universidade Federal de Sergipe (UFS).

*** Muséum National d'Histoire Naturelle/França e Programa de Pós-graduação de Arqueologia da Universidade Federal de Sergipe (UFS).
} 


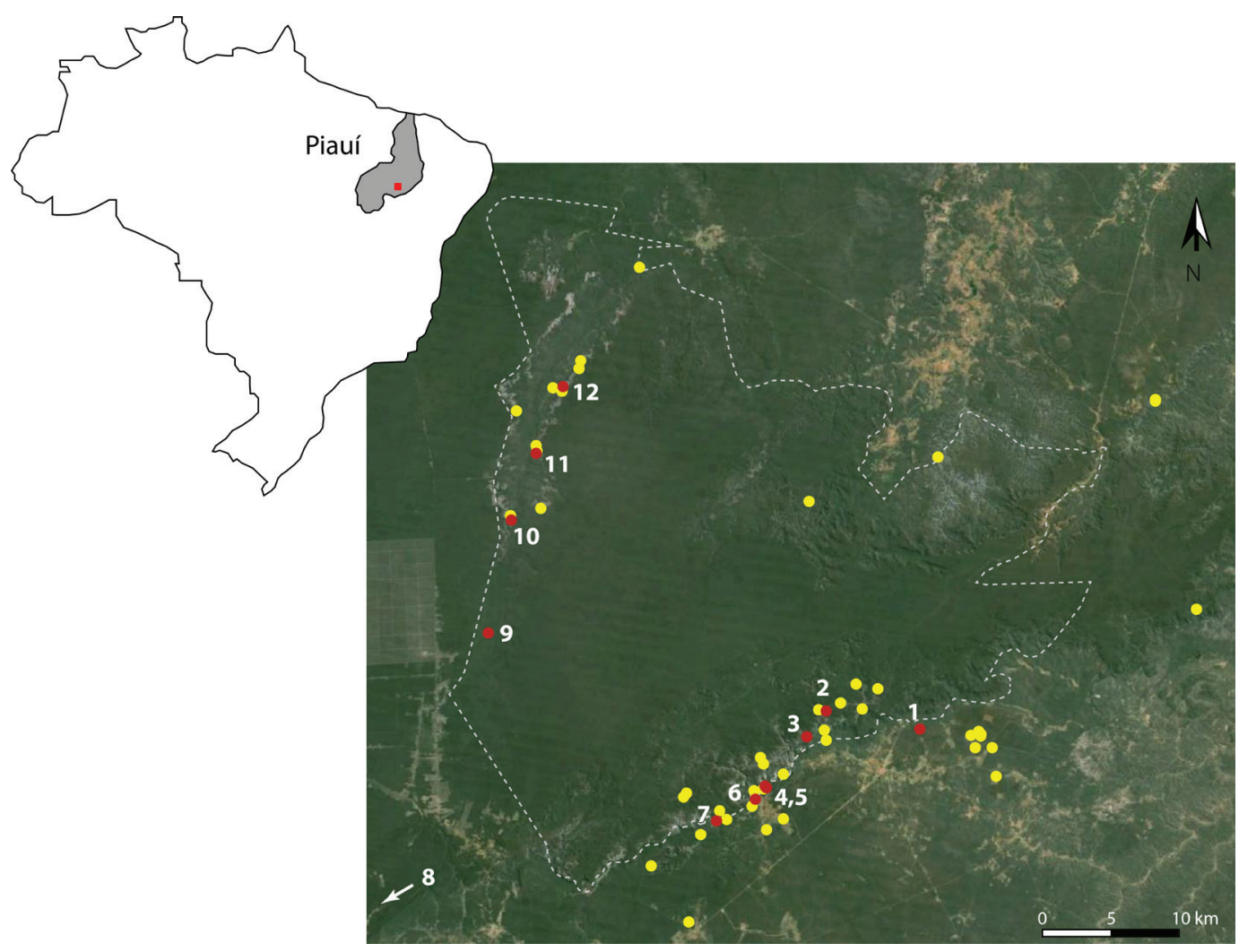

Figura 1 - Localização dos sítios arqueológicos escavados e datados na Serra da Capivara. Legenda: Em vermelho, os sítios mencionados no artigo: 1: Aldeia da Queimada Nova; 2: Toca da Baixa das Cabaceiras; 3: Toca do Baixão da Ana Maria; 4: Toca do Boqueirão da Pedra Furada; 5: Vale da Pedra Furada; 6: Toca da Cerca do Elias; 7: Toca da Ema do Sítio do Brás I; 8: Sítio Canabrava; 9: Toca do João Leite; 10: Toca do Vento; 11: Toca do Pica-Pau; 12: Toca do Veado. Os limites do Parque Nacional Serra da Capivara estão representados pela linha tracejada branca Fonte: Elaborada pelos autores (Foto satélite: Google Earth).

Na Serra da Capivara, as primeiras análises de material lítico remontam ao final dos anos 1970. Elas permitiram identificar a presença de vários tipos de instrumentos sobre lascas e seixos associados a restos de debitagem. As matérias-primas utilizadas são o quartzo, o quartzito, o sílex, a calcedônia e o siltito (GUIDON, 1978a; 1981; SANTOS; ROCHA, 1982; ROCHA, 1984). Em 1986, Guidon propôs uma primeira periodização da pré-história da região em grandes fases cronológicas. As ocupações do Pleistoceno final são relacionadas à "fase Pedra Furada", caracterizada por instrumentos sobre seixos de quartzo e quartzito e lascas retocadas debitadas sobre as mesmas matérias-primas (GUIDON, 1986). A partir da transição Pleistoceno-Holoceno, uma mudança foi observada nas indústrias líticas, associada a um aumento do número de sítios arqueológicos. Nesta primeira periodização, a percepção das indústrias líticas holocênicas ficou ainda muito ligada às variações estilísticas do registro rupestre (GUIDON, 1985, 1986). O material lítico da fase Serra da Capivara, nos abrigos com estilo de pintura do mesmo nome, é caracterizado por instrumentos sobre seixos e lascas de quartzo e quartzito, além de alguns de sílex e calcedônia, datados entre 14.000 e 8.000 AP cal. A fase Serra Talhada, nos sítios com pintura do complexo cultural desse nome, apresenta uma proporção maior do uso do sílex e é datada entre 9.000 e 7.000 anos AP cal. Ao redor de 6.000 anos AP cal, os sítios são menos numerosos e as produções líticas, associadas à Tradição Agreste, caracterizam-se por uma "técnica grosseira" (GUIDON, 1985, 1986).

Em 1993, Fabio Parenti completou e afinou este quadro cronológico, com base em um estudo detalhado do sítio Pedra Furada (PARENTI, 1993, 2001). Baseando-se parcialmente na periodização proposta por Guidon, Parenti propôs uma nova divisão crono-cultural. Para o Pleistoceno, conserva a denominação da fase Pedra Furada, datada de 49.000 a 14.000 anos AP. Trata-se de uma produção de vários tipos de instrumentos, confeccionados sobre seixos lascados uni- ou bifacialmente e sobre lascas debitadas a partir de seixos de quartzo e quartzito. 
A partir de critérios cronológicos e tecnológicos, esta fase foi dividida em três períodos (PF 1, PF 2 e PF 3). Para o Holoceno, Parenti distingue dois momentos sucessivos, a fase Serra Talhada, entre 12.200 e 7.000 anos AP cal, e a fase Agreste, não datada, mas posterior ao Holoceno médio. A fase Serra Talhada distingue-se nitidamente da anterior. Além dos seixos de quartzo e quartzito, blocos e seixos de matérias-primas alóctones (calcedônia, sílex, arenito silicificado) começam a ser utilizados. Os tipos de instrumentos produzidos sobre seixos se diferenciam daqueles da fase Pedra Furada, e novos tipos de instrumentos sobre lascas aparecem junto com as novas matérias-primas (como lesmas, plainas, raspadores convergentes etc.). A fase Agreste, composta de um baixo número de vestígios líticos, é mais difícil de caracterizar do ponto de vista técnico, mas não parece haver uma ruptura técnica profunda com o período anterior.

A sequência cultural de Pedra Furada, por sua larga abrangência cronológica e pelo fato da descrição em detalhe, foi considerada nos trabalhos posteriores como uma referência para toda a região. No entanto, a quantidade de dados coletados aumentou sensivelmente nas últimas décadas. Hoje, mais de 131 sítios já foram escavados pela FUMDHAM, dezenas de outros foram alvo de coletas de superfície, e os trabalhos de campo continuam, nomeadamente no âmbito da Missão Franco-Brasileira do Piauí coordenada por Eric Boëda (BOËDA et al., 2013; BOËDA et al., 2014; LAHAYE et al., 2013). Tal acúmulo de material e de dados completou o panorama arqueológico da Serra da Capivara e, apesar do número reduzido de análises detalhadas do material lítico dos sítios da região depois do estudo de Parenti, percebe-se que o quadro geral proposto com a sequência de referência de Pedra Furada não enquadra mais na complexidade sugerida pelos novos registros tecnoculturais e cronológicos.

Considerando essa necessidade de redefinição da sequência tecnocultural da Serra da Capivara, iniciamos, depois de uma revisão bibliográfica exaustiva, uma campanha de reanálise do material lítico de sítios escavados pela FUMDHAM. Uma primeira etapa desse trabalho já foi objeto de uma publicação no âmbito do projeto "Síntese sobre a região do Parque Nacional Serra da Capivara" coordenado por Anne-Marie Pessis (LOURDEAU; PAGLI, 2014). O presente artigo inscreve-se na sequência desse estudo inicial.

\section{Produções líticas na Toca do João Leite}

O abrigo Toca do João Leite está localizado no município de São Raimundo Nonato, a noroeste do Parque Nacional Serra da Capivara na área denominada de Serra Branca. O abrigo possui uma extensão de $50 \mathrm{~m}$ e encontra-se no primeiro nível de erosão abaixo do planalto, com abertura orientada Sudoeste/Noroeste. A sua frente, orientada para o sul, uma área de suave declive estende-se até a descida para o fundo do vale chamado de Baixão do Caixa Prego (GUIDON; PESSIS; MARTIN, 2009).

\section{Estratigrafia}

A escavação foi realizada de julho a outubro de 2006 pela equipe da FUMDHAM sob direção de Guidon. Os setores do sítio foram definidos seguindo os nichos naturais da parede rochosa e as áreas a serem escavadas pela concentração de pinturas rupestres (Figura 2, n. 1), apresentamos aqui somente o material do setor 4 central (LUCAS, 2014, 2016).

A escavação foi realizada por decapagens artificiais de $5 \mathrm{~cm}$. O sedimento é de origem coluvial, composto por areia fina e amarela. Em todas as áreas escavadas chegou-se à rocha matriz, atingindo a profundidade de $1,80 \mathrm{~m}$ na sua parte mais profunda.

A leitura estratigráfica, realizada após a escavação, a partir do corte leste do Setor 4 central, identificou cinco camadas estratigráficas (Figura 2, n. 2). Essas camadas são distinguíveis principalmente pela mudança na cor do sedimento, ocasionada pela presença de áreas de combustão e carvões dispersos. A leitura vertical dos artefatos foi feita por faixas de $1 \mathrm{~m}$, paralelas e perpendiculares à parede rochosa, e quatro diferentes níveis de material foram identificados e associados às camadas estratigráficas (Figura 2, n. 3).

- Nível 1: é composto por artefatos líticos e cerâmicos dispersos e em poucas concentrações. O conjunto está associado à camada 1 , caracterizada por um sedimento de cor amarela e à datação de $1.250 \pm 40$ anos AP cal (Beta 218507).

- Nível 2: está associado à camada 2 e apresenta material lítico em toda a extensão do pacote, $\mathrm{e}$ cerâmico apenas no contato entre a camada 1 . O sedimento é de cor cinza, e as datações são de $3.420 \pm 30$ e $5.660 \pm 45$ anos AP cal (Beta 218506 e Beta 220089 respectivamente).

- Nível 3: está associado à camada 4, com sedimento de cor cinza, e não possui datas relacionadas.

- Nível 4: está associado à camada 5, sedimento de cor cinza, e às datações de $12.440 \pm 190 \mathrm{e}$ $12.790 \pm 80$ anos AP cal (Beta 219672 e Beta 220089 respectivamente). 

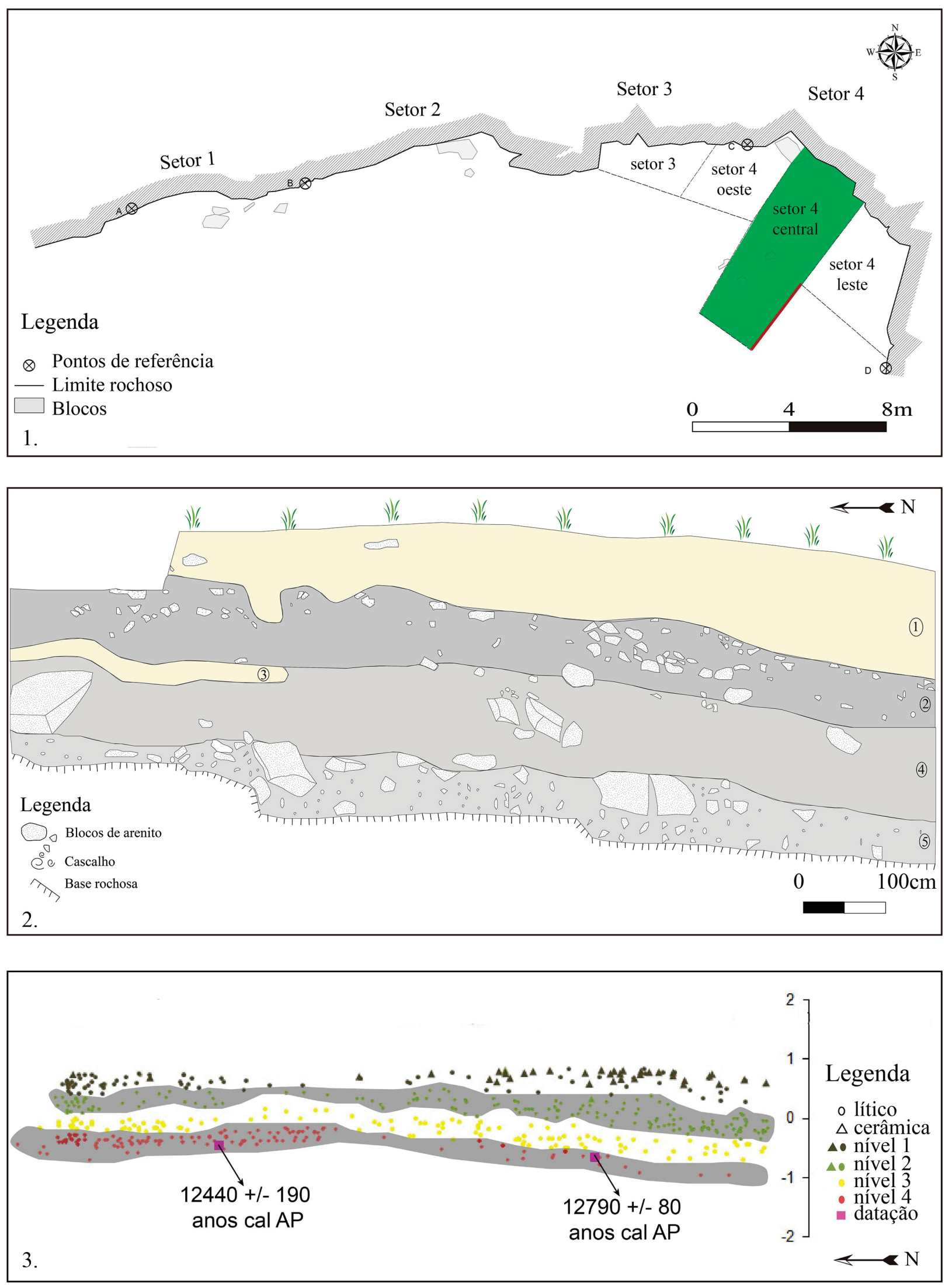

Figura 2 - Toca do João Leite.1. Plano do abrigo: em verde, a área estudada; em vermelho, o perfil de referência. 2. Perfil estratigráfico de referência. 3. Projeção longitudinal entre 8 e $9 \mathrm{~m}$ dos vestígios líticos, cerâmicos e dos carvões datados encontrados no setor 4 central: em cinza, os níveis estudados.

Fonte: Elaborada pelos autores, com base no arquivo da FUMDHAM. 


\section{Indústrias líticas}

Apresentamos aqui as principais características técnicas dos conjuntos líticos presentes no nível 4 e no nível 2 do setor 4 central.

\section{Nível 4}

Este nível é composto por 321 peças, das quais 45 são instrumentos e 12 são núcleos, realizados a partir de arenito silicificado, quartzo, sílex, quartzito, arenito e calcedônia. As principais características técnicas deste conjunto são:

- o uso marcante do façonnage, principalmente na modalidade unifacial, para produção tanto de instrumentos do tipo Itaparica (sensu LOURDEAU, 2014) quanto de outros instrumentos;

- quatro objetivos de lascamento ligados a quatro diferentes tipos de suportes.

O primeiro objetivo de lascamento são os instrumentos (oito peças) façonados unifacialmente do tipo Itaparica, produzidos a partir de lascas de grandes dimensões que após o façonnage adquiriram características espessa e alongada (Figura 3, n. 1). Essas peças apresentam potenciais funcionais variados, com partes transformativas localizadas principalmente na extremidade apical, mas podendo se estender até os lados. São peças suporte de instrumentos.

O segundo objetivo são os instrumentos (dez peças) façonados unifacialmente cujo suporte inicial é uma lasca mais larga que comprida (Figura $3, \mathrm{n}$. 2). Após façonado, o volume ganhou características espessa e alongada e foi utilizado para produzir uma parte transformativa específica localizadas na lateral da peça, com gume com delineamento linear e ângulos abruptos.

O terceiro objetivo são os instrumentos (seis peças) sobre lascas, produzidos a partir de lascas finas e alongadas (Figura 3, n. 3). São instrumentos com volume normatizado, que apresentam a parte transformativa localizada na lateral da peça com delineamento linear e com ângulos agudos.

O quarto objetivo são os instrumentos (21 peças) sobre lascas, produzidos a partir de lascas de pequenas dimensões e espessas (Figura 3 , n. 4). São instrumentos pouco modificados que apresentam partes transformativas com delineamento, principalmente, côncavo e linear com ângulos agudos.

Os núcleos presentes nesse conjunto apresentam uma exploração em séries curtas e unidirecionais feitas a partir das convexidades naturais do bloco (Figura 3, n. 5). São peças pouco exploradas e seus produtos condizem com os suportes utilizados na produção do quarto objetivo de lascamento. Portanto, os outros suportes utilizados foram provavelmente introduzidos já lascados no abrigo.

\section{Nível 2}

O nível 2 é composto por um conjunto de 684 peças líticas, sendo 41 instrumentos e 20 núcleos produzidos em arenito silicificado, quartzo, sílex, quartzito e arenito. A indústria desse conjunto tem como principais características técnicas:

- a produção de instrumentos a partir de lascas, seixos e fragmentos de morfologia variada;

- instrumentos variados caracterizados pela presença de partes abruptas e/ou oblíquas.

As características da parte transformativa definem os tecnotipos de instrumentos desse conjunto. Essas peças apresentam pouca modificação no suporte e as partes transformativas geralmente foram produzidas no momento da debitagem da lasca, ou por uma única retirada sem retoques posteriores.

Os instrumentos com parte transformativa linear são encontrados sobre suportes alongados, não alongados, quadrangulares e triangulares, e apresentam um ou mais dorsos formados por partes abruptas geralmente opostas ou adjacentes à parte ativa da peça (Figura 4, n. 1, 2). 


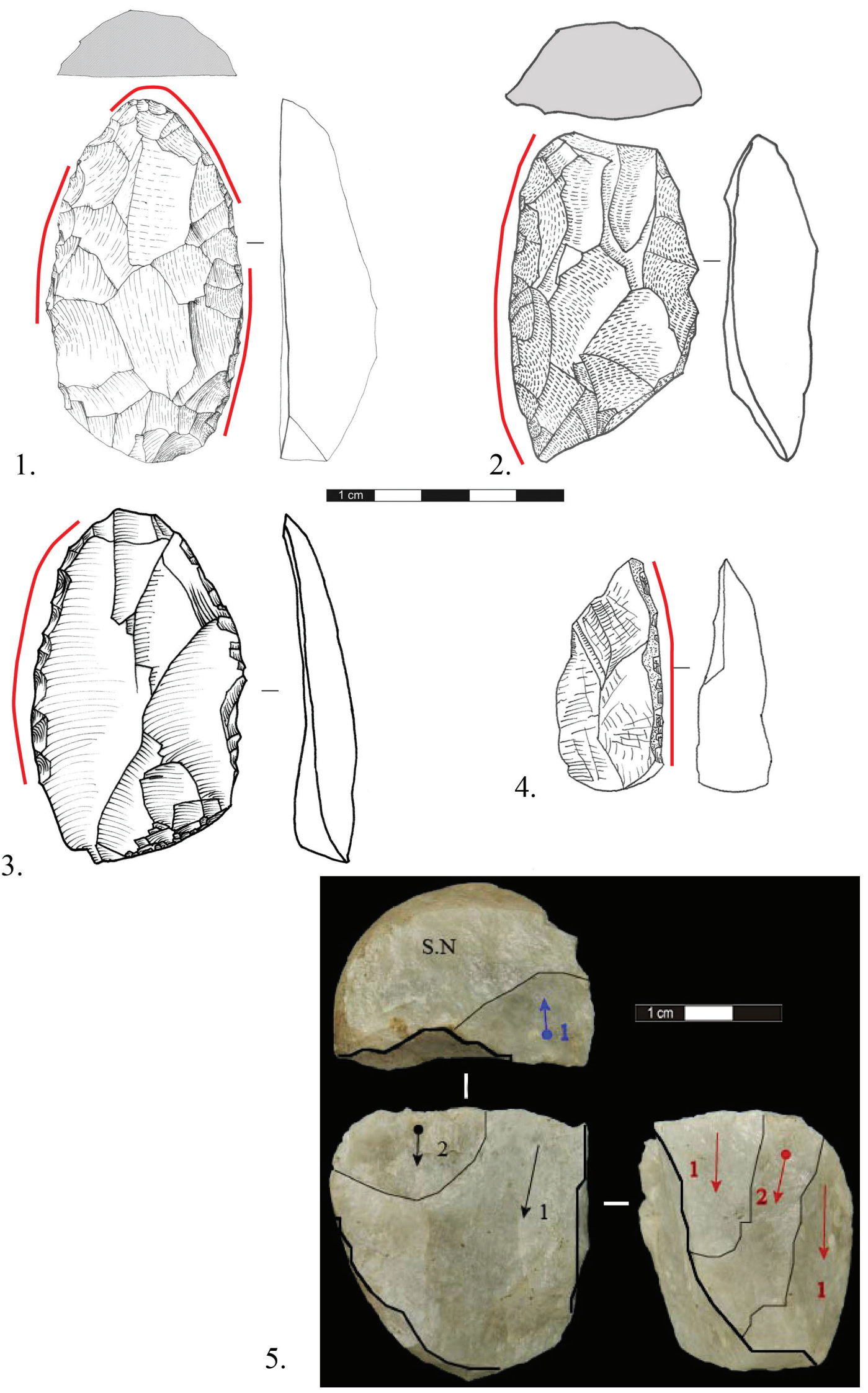

Figura 3 - Toca do João Leite. Instrumentos e núcleo do nível 4. Em vermelho, as partes transformativas Fonte: Elaborada pelos autores. 


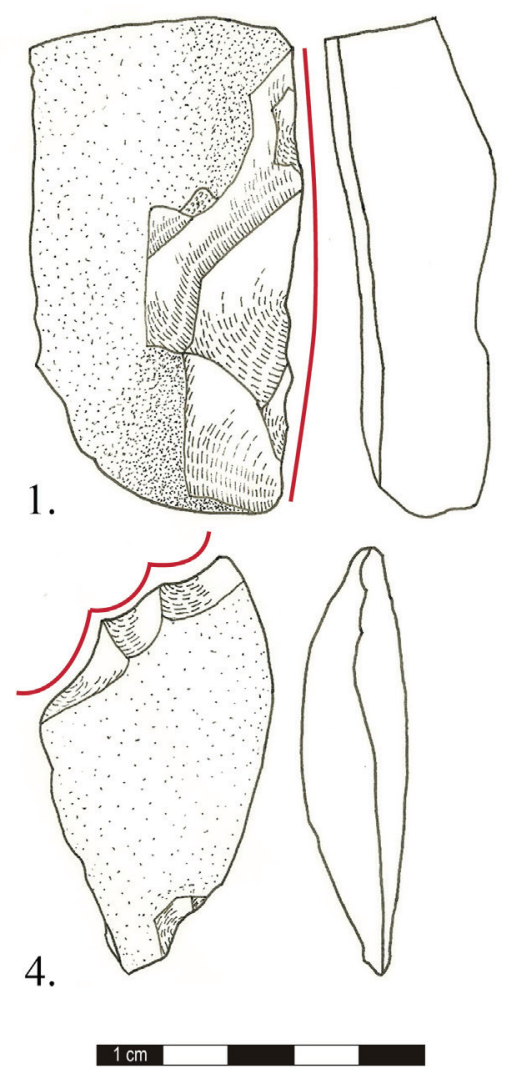

2.
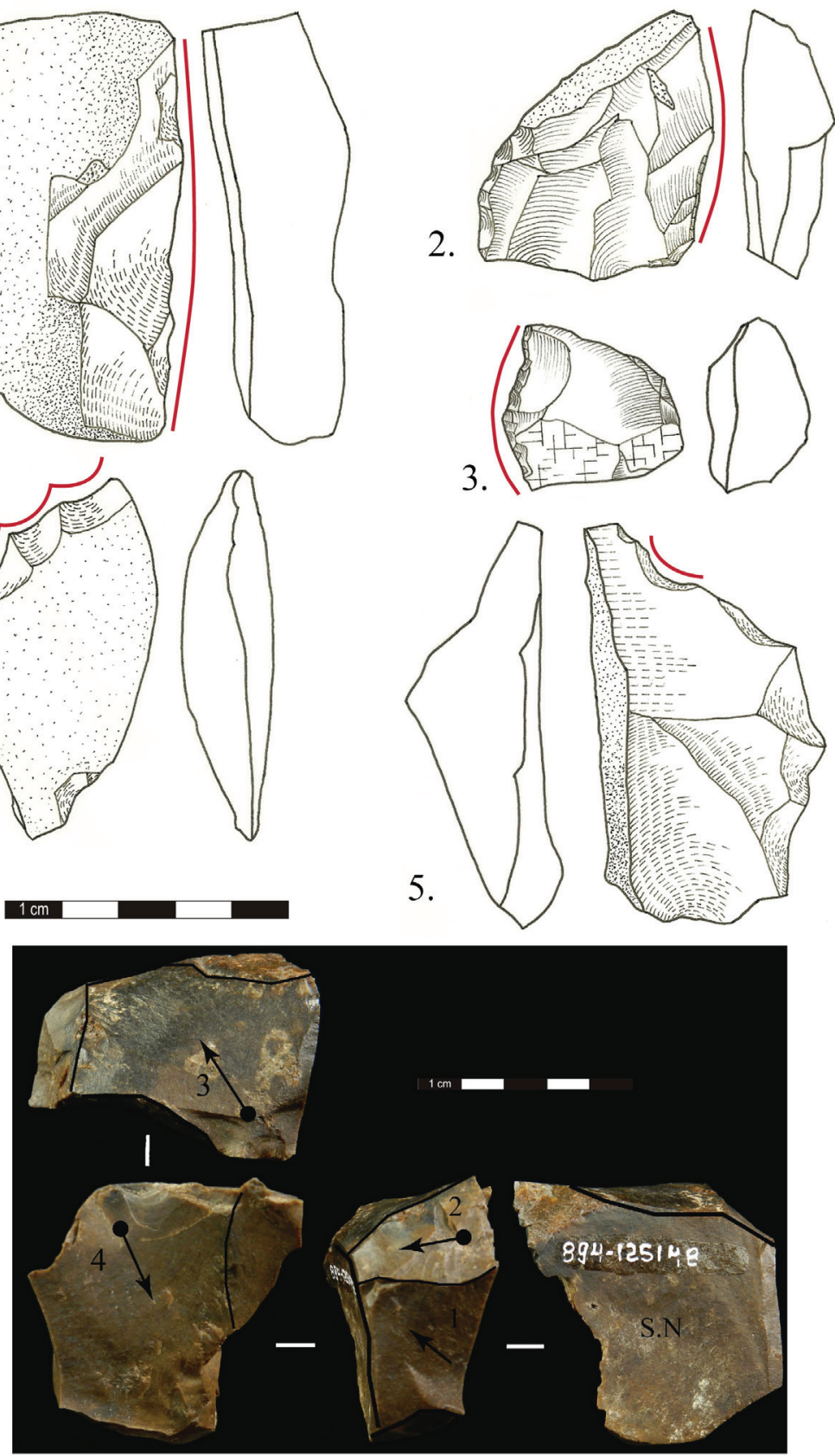

Figura 4 - Toca do João Leite. Instrumentos e núcleos do nível 2. Em vermelho, as partes transformativas Fonte: Elaborada pelos autores.

Os instrumentos com parte ativa denticulada foram produzidos sobre suportes não alongados que se diferenciam pela localização do dorso oposto ou adjacente à parte ativa; sobre suporte alongado com parte ativa em uma extremidade e lados paralelos abruptos; e sobre suporte quadrangular com três lados abruptos (Figura 4, n. 3, 4).

Os instrumentos com parte ativa côncava foram produzidos sobre suporte alongado e suporte de pequenas dimensões, e em ambos os casos as peças apresentam mais de uma superfície abrupta (Figura 4, n. 5).

Os núcleos desse nível apresentam exploração em séries curtas e retiradas paralelas, geralmente feitas por método unidirecional (Figura 4, n. 6). Os produtos dessas peças são lascas de morfologia variada que condizem com os suportes utilizados na produção dos instrumentos do conjunto. 


\section{Produções líticas na Toca da Ema do Sítio do Brás I}

A Toca da Ema do sítio do Brás I está localizada na região sudeste do Parque Nacional Serra da Capivara, perto de um vale que entalha a cuesta arenítica. Trata-se de um abrigo extenso, com uma largura de aproximativamente $80 \mathrm{~m}$, com a abertura orientada ao Sul (Figura 5, n. 1). As escavações foram realizadas em vários setores do abrigo: na zona oeste (setores 1A e 1B) e na zona leste (setores 2A e 2B; setor 2C) (GUIDON; PESSIS; MARTIN, 2009). A escavação foi realizada por meio de decapagens artificiais.

\section{Estratigrafia}

A análise concentrou-se no setor $1 \mathrm{~A}, \mathrm{o}$ mais rico de material arqueológico. A estratigrafia, nesse setor, é composta de duas camadas de areia, uma superficial e uma basal, em contato com a base rochosa e, entre as duas, uma camada de areia com cinzas e carvão (Figura 5, n. 3). A distribuição vertical do material lítico segundo faixas de $1 \mathrm{~m}$ de largura mostra principalmente uma fase de ocupação marcada por um único nível arqueológico (Figura 5, n. 2), o qual parece estar associado à camada com cinzas e carvão. Uma datação de $9.915 \pm 170$ AP cal (Beta 153987) foi obtida a partir de um carvão posicionado no meio da concentração dos vestígios líticos do setor 1A (Figura 5, n. 2) e sugere uma atribuição desse nível de ocupação a uma fase antiga do Holoceno. Outras datações similares $(9.120 \pm 100$ AP cal, Beta 148102, e $9.140 \pm 90$ AP cal, Beta 148100) no setor $2 \mathrm{~A}$ sugerem que a ocupação mais intensa do abrigo aconteceu durante essa fase cronológica. Porém, uma datação mais recente, de $5.470 \pm 100$ AP cal (Beta 148101), no setor 2B, testemunha uma ocupação mais recente do abrigo.

\section{Indústria lítica}

O conjunto do setor $1 \mathrm{~A}$ é constituído por 459 peças lascadas, dentro das quais 35 instrumentos retocados e 44 núcleos. As matérias-primas mais utilizadas foram o quartzito e o quartzo, mas algumas peças de sílex são igualmente atestadas.
Os instrumentos mostram volumes e gumes diversificados, mas entre os quais é possível identificar algumas estruturas volumétricas recorrentes.

O primeiro grupo é caracterizado por instrumentos com volumes alongados com uma parte transformativa localizada no lado mais curto do instrumento (Figura 6, n. $1-4$ ). Os tamanhos dos instrumentos desse grupo são variados. Os suportes iniciais são constituídos de lascas mais compridas que largas (Figura 6, n. 2, 4) ou de blocos angulares naturais que apresentam uma secção transversal plano-convexa (Figura 6, n. 1, 3). As partes transformativas realizadas são variadas: gumes de delineamento convexo, lineares ou denticulados (Figura 6, n. 1) e gumes de delineamento retilíneo, lineares (Figura 6, n. 4) e denticulados (Figura 6, n. 3) são presentes. O delineamento convergente é também atestado (Figura 6, n. 2). Nos lados mais compridos dos suportes e no lado mais curto oposto ao gume, podem-se observar partes abruptas corticais ou formadas por negativos abruptos e pelo talão no caso das lascas ou por superfícies naturais no caso dos suportes naturais.

O segundo grupo contém os instrumentos não alongados, com uma parte transformativa em um dos lados (Figura 6, n. 5 - 7). Os suportes iniciais são representados sobretudo por lascas. As partes transformativas são variadas: gumes denticulados de delineamento convexo (Figura 6, n. 7) ou reentrâncias (Figura 6, n. 6). As peças de espessura reduzida apresentam gumes lineares retilíneos (Figura 6, n. 5).

O façonnage unifacial está ausente no setor 1A. Essa ausência parece surpreendente no contexto da transição Pleistoceno-Holoceno antigo da área. Porém, alguns indicadores da presença do façonnage unifacial provêm dos setores $1 \mathrm{~B}$ e $2 \mathrm{~A}$ do abrigo. Trata-se de uma lasca de reavivamento de uma peça façonada unifacialmente (Figura 6, n. 8) e de duas lascas de façonnage (Figura 6, n. 9, 10). Essas peças testemunham, em negativo, a existência desse tipo de suporte e da concepção de produção por façonnage unifacial. 

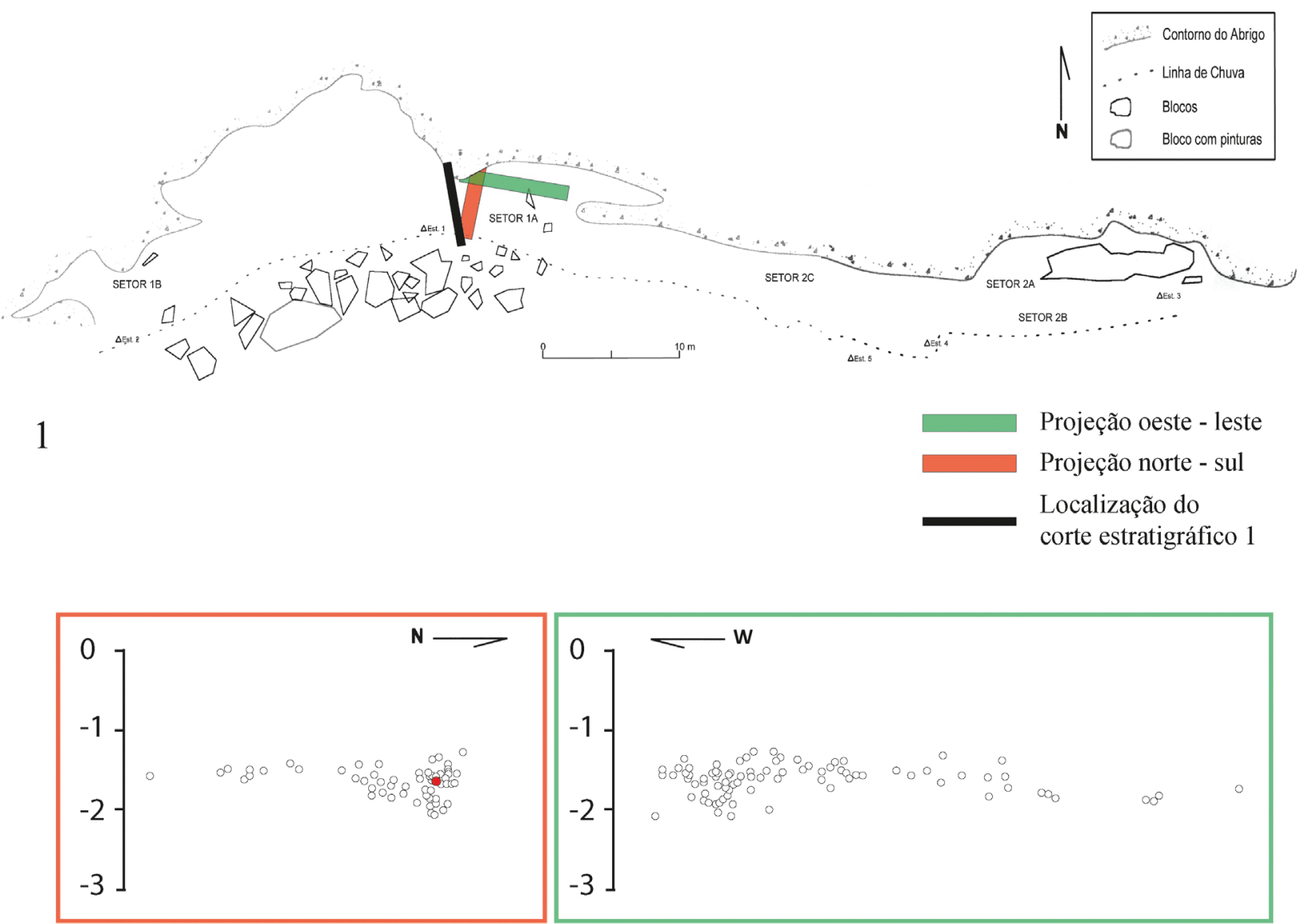

2

Projeção oeste - leste

Projeção norte - sul

Vestígios líticos

- Datação $9915 \pm 170$ AP cal

Cód. 42 - Toca da Ema do São Brás I

Corte estratigráfico 1

Setor $1 \mathrm{~A}$

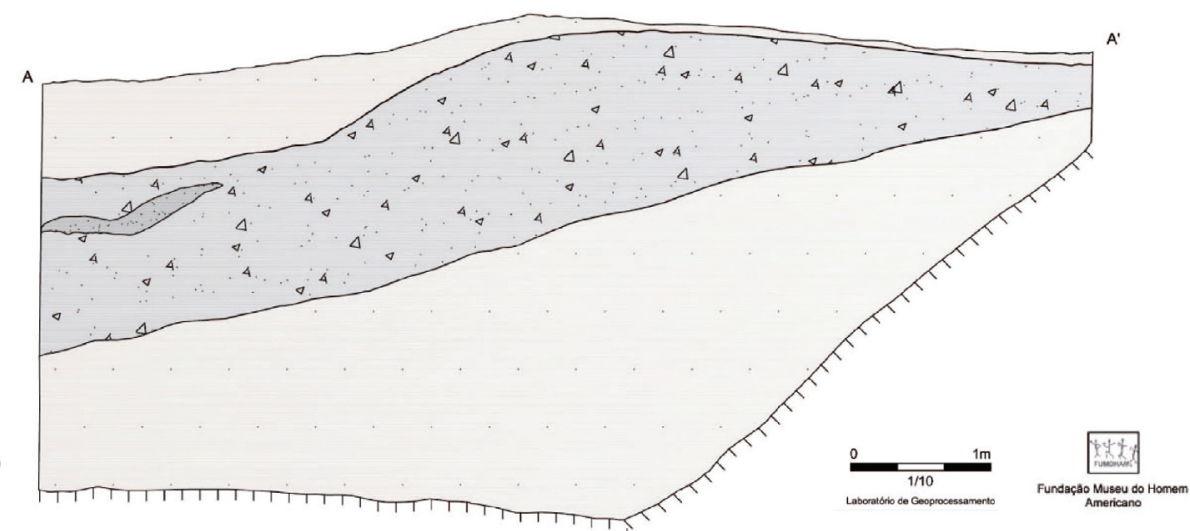

3

Figura 5 - Toca da Ema do sítio do Brás I: 1. Plano do abrigo e localização das áreas escavadas; 2. Projeções verticais dos vestígios líticos. 3. Perfil estratigráfico do setor $1 \mathrm{~A}$.

Fonte: Elaborada pelos autores, com base no Arquivo da FUMDHAM. 
Três métodos de produção podem ser identificados no conjunto dos instrumentos:

- Exploração de peças naturais (seixos arredondados ou blocos angulares), cujas características volumétricas foram utilizadas para a obtenção dos instrumentos, depois do retoque da parte transformativa ou das partes preensivas.

- Debitagem de lascas: as lascas suportes de instrumentos são principalmente corticais ou semicorticais (Figura 6, n. 2, 4, 5, 7). A análise dos negativos da face superior mostra que as lascas suportes de instrumentos foram obtidas por séries unidirecionais (Figura 6 , n. 4, 5) ou ortogonais (Figura 6, n. 6). Esses dados sugerem a existência de uma debitagem por curtas sequências de retiradas de direção unidirecional ou ortogonal.

- Façonnage unifacial: a presença de lascas de reavivamento e de façonnage nos setores $1 \mathrm{~B}$ e $2 \mathrm{~A}$ demonstra indiretamente que peças façonadas unifacialmente foram produzidas e utilizadas no abrigo.

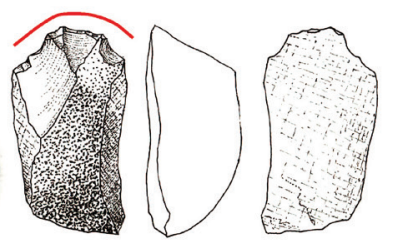

2.
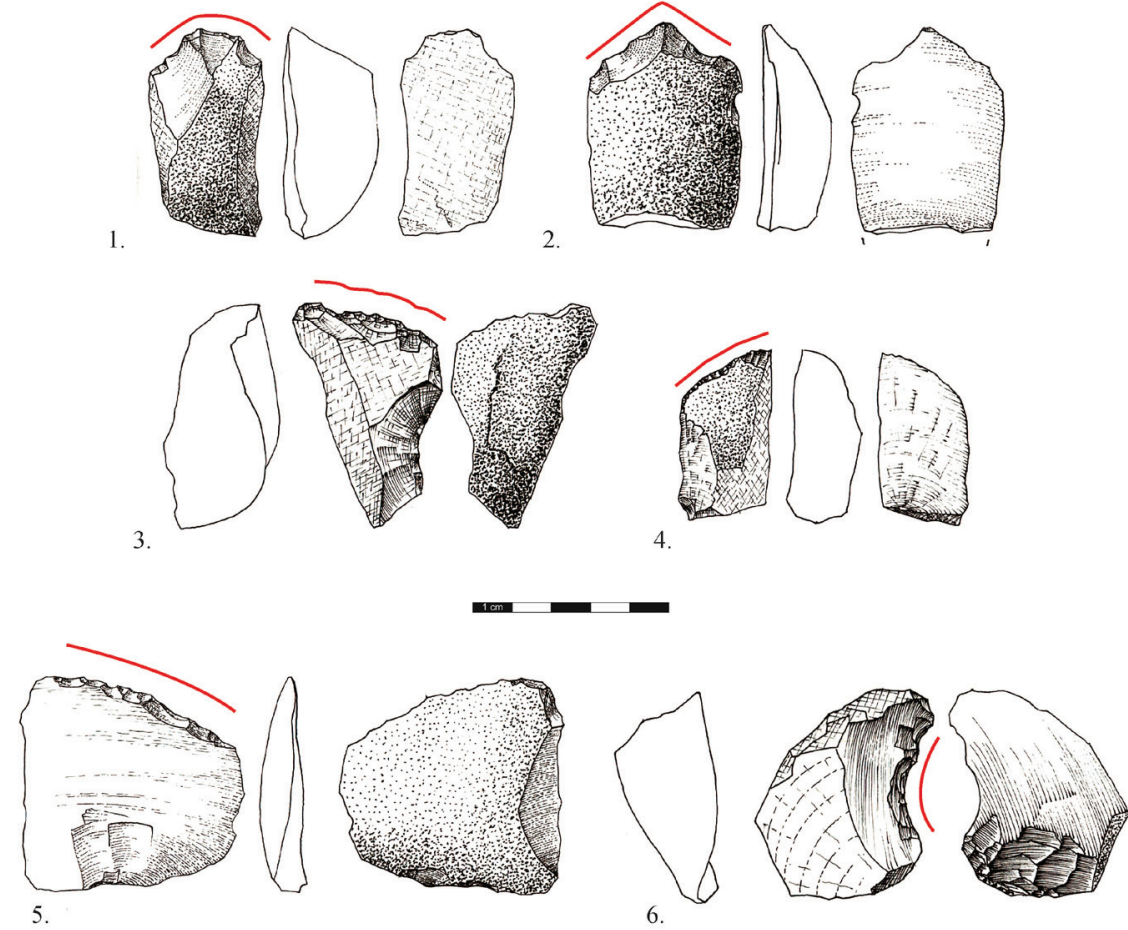

6 .
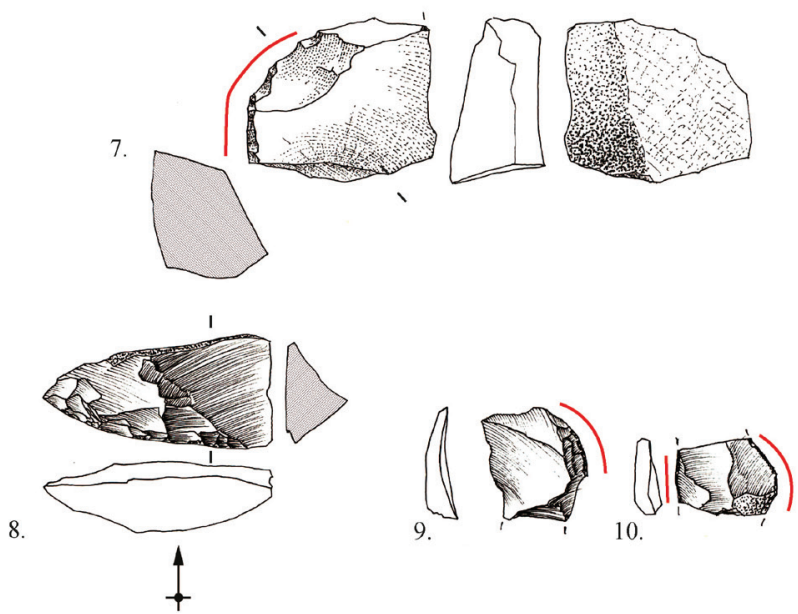

Figura 6 - Toca da Ema do sítio do Brás I: instrumentos. 1 - 7: setor 1A; 8: setor 2A; 9, 10: setor 1B. Em vermelho: as partes transformativas.

Fonte: Elaborada pelos autores. 


\section{Produções líticas na Toca do Baixão da Ana Maria}

A Toca do Baixão da Ana Maria está localizada na área meridional do Parque Nacional Serra da Capivara, a uma altitude de cerca 490 $\mathrm{m}$. Trata-se de um grande abrigo sob rocha, de aproximativamente $67 \mathrm{~m}$ de largura com a abertura orientada ao Sul-Leste (Figura 7, n. 1) (GUIDON; PESSIS; MARTIN, 2009). O sítio foi descoberto em 2007 e escavado durante duas campanhas em 2008 e 2009. Várias sondagens foram realizadas, e as mais ricas em vestígios líticos foram as sondagens localizadas perto do paredão rochoso: a sondagem 1 , ampliada sucessivamente por uma trincheira (trincheira 2) e a sondagem 2 (Figura 7, n. 1).

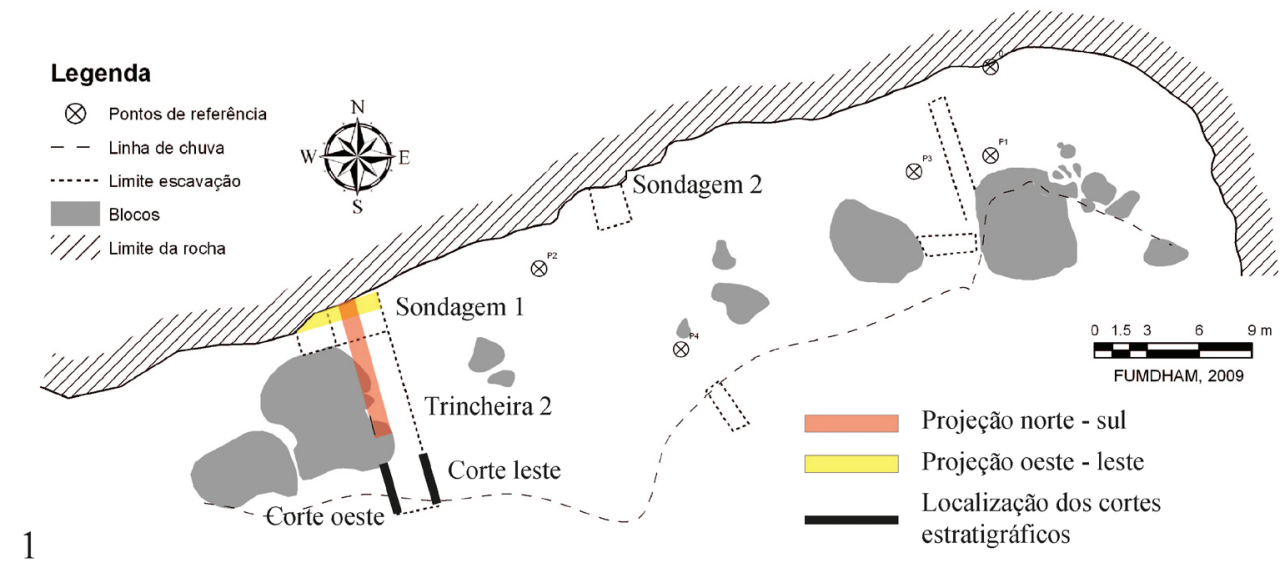

2
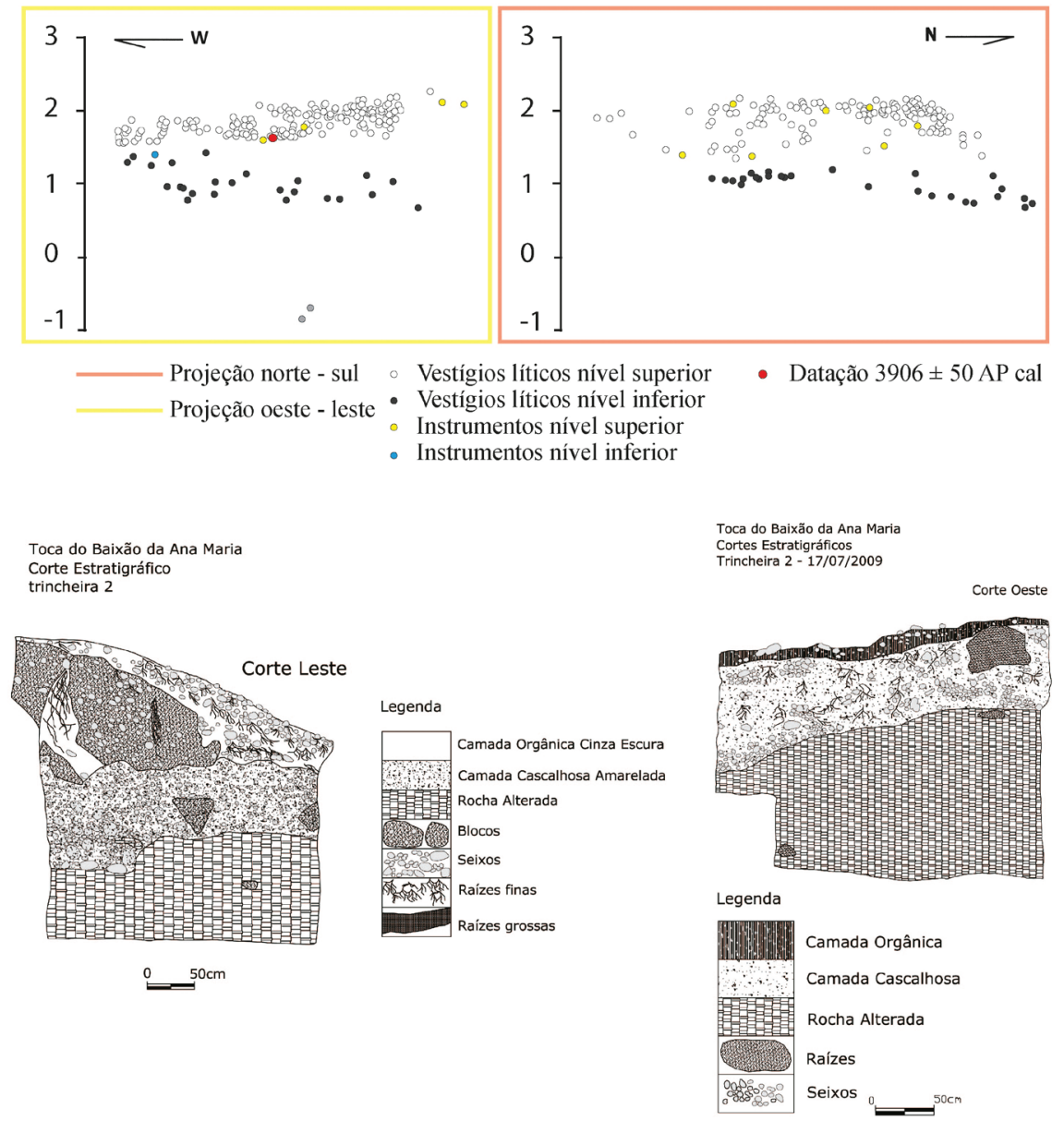

Figura 7 - Toca do Baixão da Ana Maria: 1. Plano do abrigo e localização das áreas escavadas; 2. Projeções verticais dos vestígios líticos. 3: Perfis estratigráficos Oeste e Leste da trincheira 2. Fonte: Elaborada pelos autores, com base no arquivo da FUMDHAM. 


\section{Estratigrafia}

A sequência estratigráfica do sítio é formada por duas camadas: uma camada superior composta de sedimento orgânico e uma camada inferior formada por cascalho, a qual se apoia na rocha base alterada (Figura 7, n. 3) (GUIDON; PESSIS; MARTIN, 2009).

A escavação foi realizada por decapagens artificiais, e a associação entre as camadas e os artefatos líticos não foi realizada durante o trabalho do campo. Então, a distinção entre os vários conjuntos arqueológicos deve ser realizada por meio das projeções verticais das posições dos vestígios líticos encontrados. Tais projeções, segundo faixas de $1 \mathrm{~m}$ de largura, nos eixos longitudinal e transversal da área escavada permitem a diferenciação de dois conjuntos arqueológicos (Figura 7, n. 2).

- O nível arqueológico superior é constituído por uma concentração de material lítico localizada na parte mais superficial da sequência, ao redor de $1,6 \mathrm{~m} / 2 \mathrm{~m}$ acima do ponto 0 de referência, e possui a quantidade mais importante de artefatos. Uma datação de $3.906 \pm 50 \mathrm{AP}$ cal (Beta 260076) foi realizada a partir de um carvão associado a esse conjunto arqueológico. A maioria dos instrumentos encontrados pertence a esse nível de ocupação.

- O nível arqueológico 2 é localizado a uma profundidade de $1 \mathrm{~m} / 1,30 \mathrm{~m}$ acima do ponto 0 de referência, e o material e os instrumentos encontrados são menos numerosos.

\section{Indústria lítica}

Os artefatos líticos encontrados são constituídos de 851 peças lascadas, dentro das quais 49 instrumentos retocados e 122 núcleos. A matériaprima mais utilizada foi o quartzito, mas o quartzo é também atestado. Apresentamos aqui os resultados da análise do material lítico do nível arqueológico 1, com o maior número de vestígios líticos, entre os quais uma quantidade importante de instrumentos.

Nessa indústria, o façonnage unifacial, bem como o façonnage bifacial, são ausentes. O traço mais marcante e original do conjunto instrumental do sítio é a presença de instrumentos sobre seixo de grande tamanho (aproximativamente entre 8 e $15 \mathrm{~cm}$ ) e de espessura importante. Além dessa característica, o conjunto dos instrumentos é pouco variado do ponto de vista das estruturas volumétricas, mas bem diversificado do ponto de vista das partes transformativas realizadas. Três grupos de suportes puderam ser identificados.

O primeiro grupo abrange os instrumentos caracterizados por um volume não alongado, com uma espessura importante e uma secção transversal plano-convexa (Figura 8, n. 1-6). Esses instrumentos foram realizados principalmente sobre seixos (Figura 8, n. $1-3,5,6$ ) ou, em menor proporção, sobre lascas espessas (Figura 8, n. 4). Apresentam partes transformativas diversificadas: lineares retilíneas (Figura 8, n. 1) ou convexas (Figura 8, n. 4) e denticuladas (Figura 8, n. 3, 6). A realização de uma parte transformativa convergente representa uma tendência forte na obtenção dos instrumentos (Figura 8, n. 2, 5). Nos lados opostos e adjacentes ao gume, podem-se observar partes abruptas naturais ou, no caso de um dos instrumentos sobre lasca, retocadas (Figura 8, n. 4).

O segundo grupo é caracterizado por instrumentos levemente alongados com uma parte transformativa realizada ao longo do lado mais comprido do suporte (Figura 8, n. 7, 8). Trata-se de suportes naturais com superfícies corticais ou naturais que apresentam uma espessura menos importante que os instrumentos do primeiro grupo. As partes transformativas obtidas são constituídas por gumes lineares retilíneos (Figura $8, n$. 7) ou levemente denticulados (Figura 8, n. 8).

Oterceiro grupo é constituído de instrumentos alongados e espessos, com uma parte transformativa localizada no lado mais curto do suporte (Figura 8, n. 9). Os suportes iniciais são seixos ou blocos naturais, com uma secção transversal plano-convexa ou biconvexa. As partes transformativas realizadas são representadas por gumes lineares retilíneos ou denticulados.

As informações relativas à fase de produção dos suportes legíveis a partir dos instrumentos permitem identificar dois métodos de produção: o primeiro é o método predominante nessa indústria: a seleção de peças naturais (seixos arredondados ou blocos angulares) com características volumétricas específicas. No segundo método, os instrumentos sobre lascas testemunham uma debitagem de lascas grandes e espessas. A grande proporção de córtex e superfícies naturais nas lascas e a direção dos negativos das retiradas anteriores na face superior atestam um método de debitagem por curtas sequências de unidirecionais e ortogonais. 

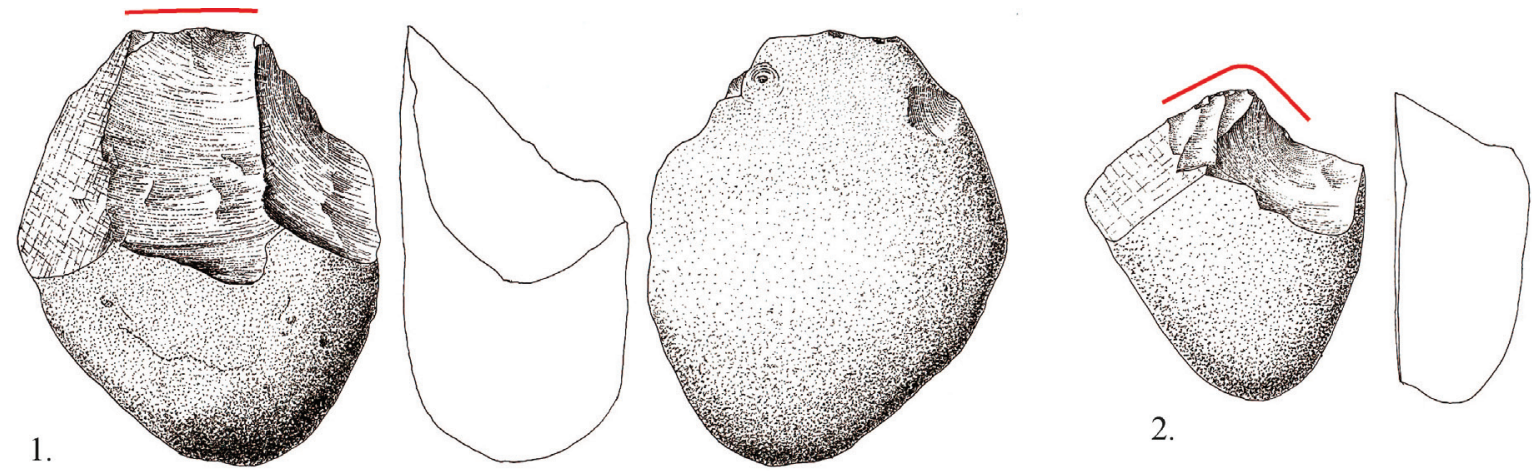

2
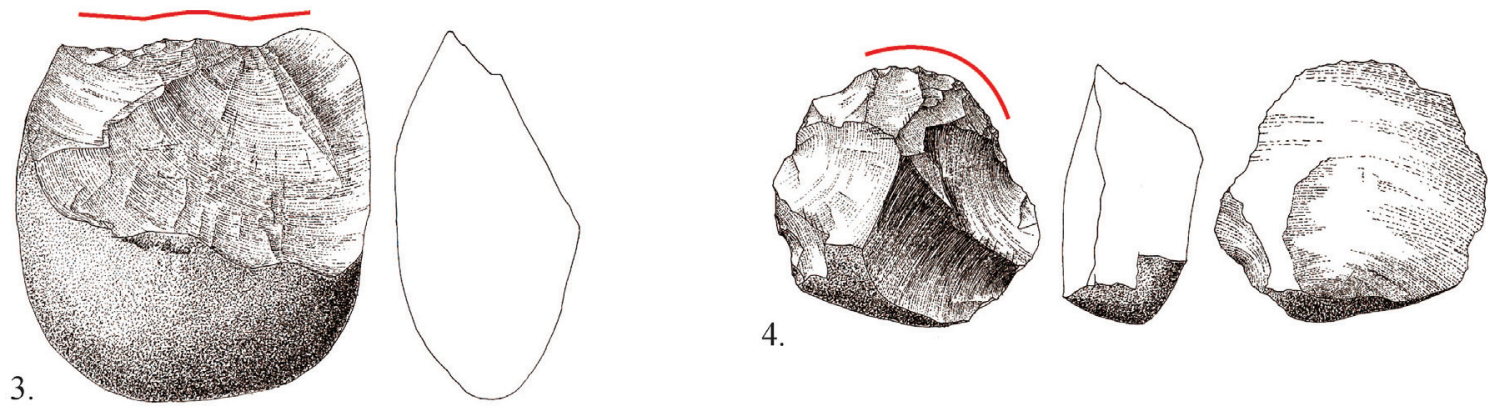

3

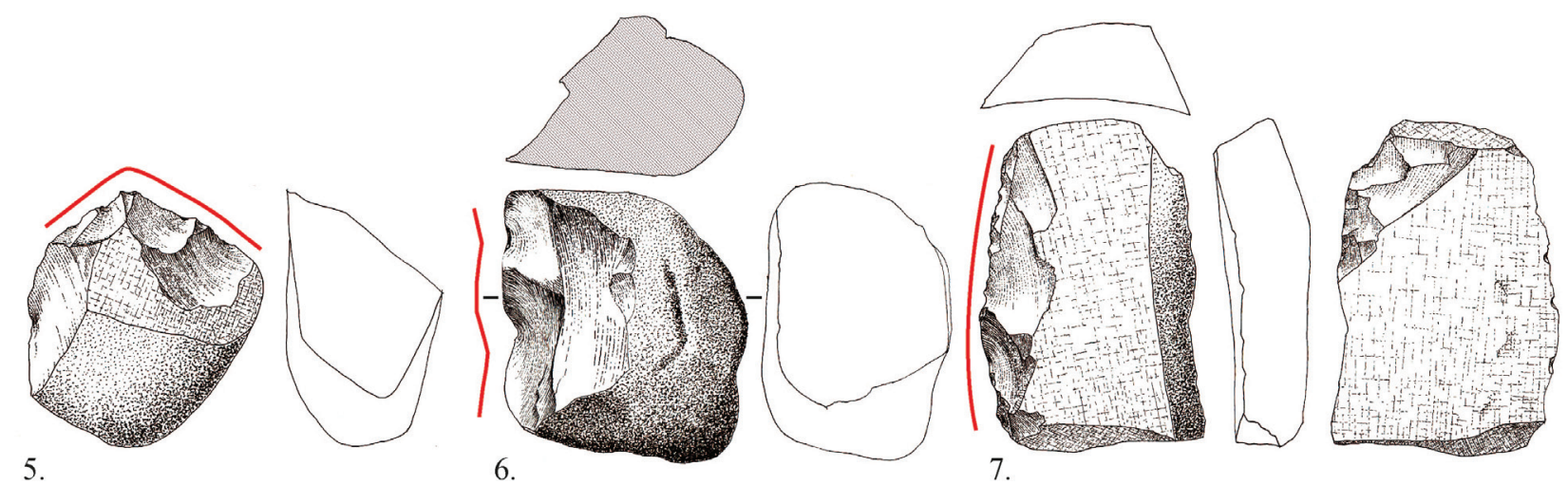

5 .

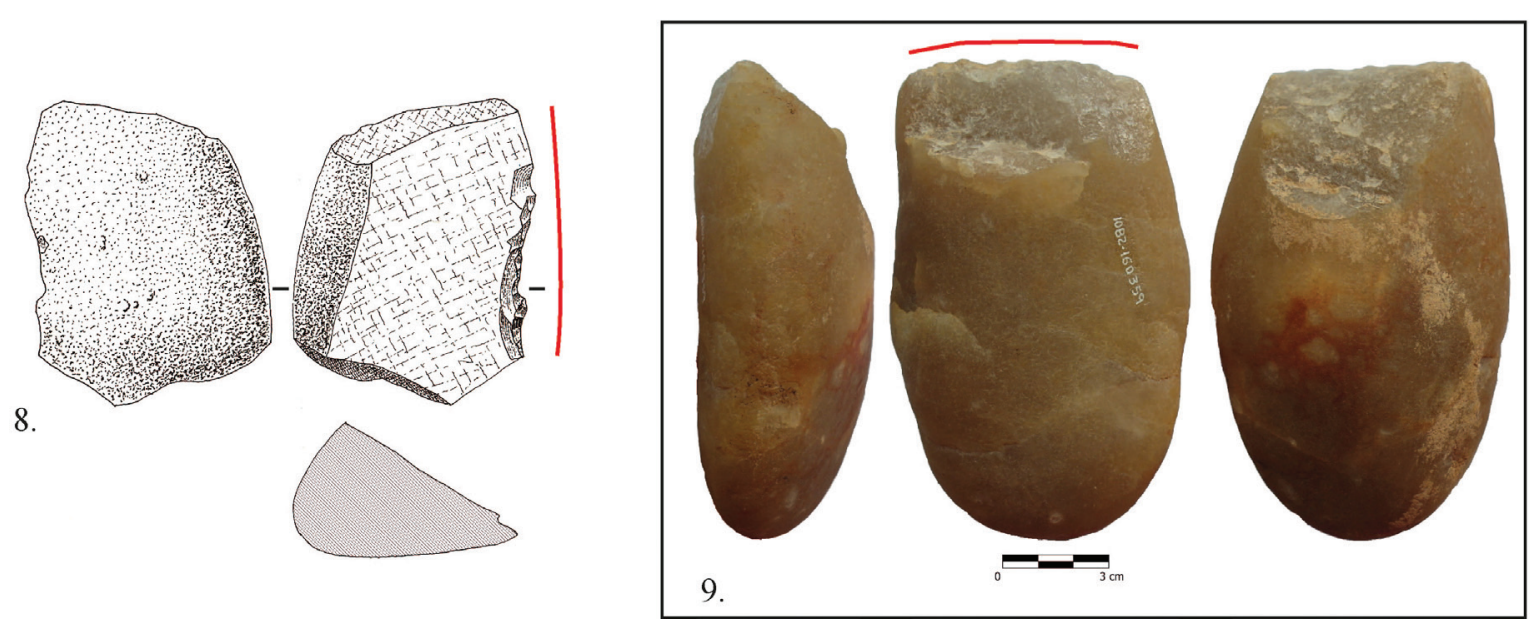

Figura 8 - Toca do Baixão da Ana Maria: instrumentos do nível superior. Em vermelho, as partes transformativas Fonte: Elaborada pelos autores. 


\section{Revisão bibliográfica das produções líticas na Serra da Capivara do Pleistoceno final ao Holoceno recente}

Os sítios arqueológicos da região mencionados na literatura são muito numerosos, mas os dados sobre os vestígios líticos resumemse geralmente a considerações tipológicas gerais. Como a abordagem tipológica é pouco eficiente no contexto da pré-história brasileira para definir conjuntos tecnoculturais (LOURDEAU, 2013), nós nos referimos aqui a sítios com indústrias publicadas por meio de análises tecnológicas que permitem entender os sistemas técnicos e compará-los com aqueles descritos acima.

\section{Boqueirão da Pedra Furada}

Trata-se de um dos abrigos mais amplos da Serra da Capivara. Foi escavado quase integralmente, entre 1978 e 1987 (PARENTI, 2001). Como frisamos na introdução, a sequência arqueológica da Toca do Boqueirão do Sítio da Pedra Furada foi separada em três grandes fases cronológicas: Pedra Furada (PF 1, 2 e 3) entre 50.000 e 14.000 AP, Serra Talhada (ST 1 e 2) entre 10.400 e $6.150 \mathrm{AP}$ cal e Agreste, não datado, na parte superficial da sequência.

$\mathrm{O}$ material lítico associado às fases Pedra Furada foi produzido a partir de seixos de quartzo e quartzito. Alcança um total de 390 peças, dentro das quais 110 seixos lascados, 66 núcleos e 63 lascas retocadas (PARENTI, 2001) (Figura 9, n. 1 - 3). Dois grandes esquemas operatórios estão presentes: um façonnage de seixos unifacial e bifacial, e uma debitagem (bipolar sobre bigorna na maioria dos casos). Existe, no geral, uma complementaridade entre estes dois esquemas operatórios do ponto de vista dos potenciais funcionais dos objetivos de lascamento. No entanto, algumas categorias de instrumentos produzidos sobre seixos, às vezes, são confeccionadas a partir de lascas bipolares (splits).

Nas fases datadas do Holoceno, aparece o uso de blocos e seixos de calcedônia, sílex e arenito silicificado, além dos seixos de quartzo e quartzito. $\mathrm{Na}$ fase Serra Talhada, constata-se um nítido aumento do número de vestígios lascados (mais de 6.000) (PARENTI, 2001). Existem três grandes objetivos de lascamento, cada um associado a um esquema operatório específico (LOURDEAU, 2010, 2015, 2016). Instrumentos de grande porte são produzidos sobre seixos de quartzo e quartzito (e às vezes, grandes lascas) (Figura 10, n. 1). Estes seixos lascados apresentam diferenças estruturais com aqueles do Pleistoceno, o lascamento bifacial sendo quase ausente. Outro objetivo, os instrumentos sobre lascas são produzidos principalmente em sequências de debitagem curtas e unidirecionais, sem preparação preliminar do núcleo. E, apesar da variedade desses instrumentos, existe uma homogeneidade da estrutura volumétrica, a maioria deles apresentando um gume lateral, oposto a um dorso (Figura 10, n. 2,3). O terceiro objetivo principal desta indústria corresponde às peças façonadas unifacialmente - chamadas lesmas ou plainas em Parenti (2001) (Figura 10, n. 4). São matrizes suportes de instrumentos variados, com uma parte transformativa em uma extremidade, eventualmente associada a outras partes transformativas na periferia da peça (LOURDEAU, 2014). Existe uma complementaridade dos potenciais funcionais entre os instrumentos sobre lascas e aqueles sobre estes suportes façonados unifacialmente. Uma ponta de projétil de quartzo foi também encontrada associada a essa indústria.

A fase Agreste, mais recente, mas sem datas absolutas, ainda falta de uma caracterização tecnológica detalhada. 


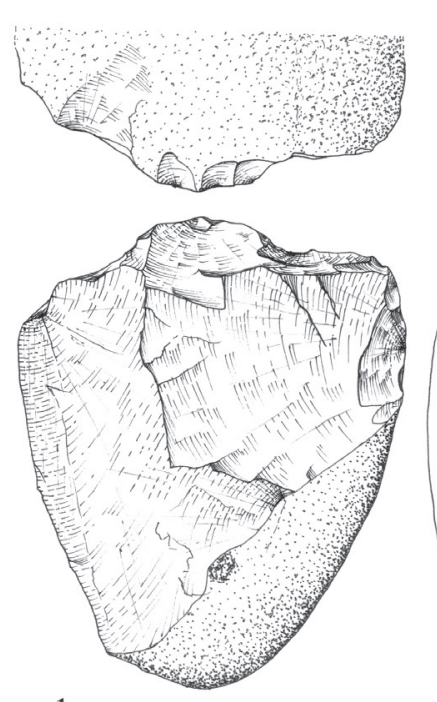

1.
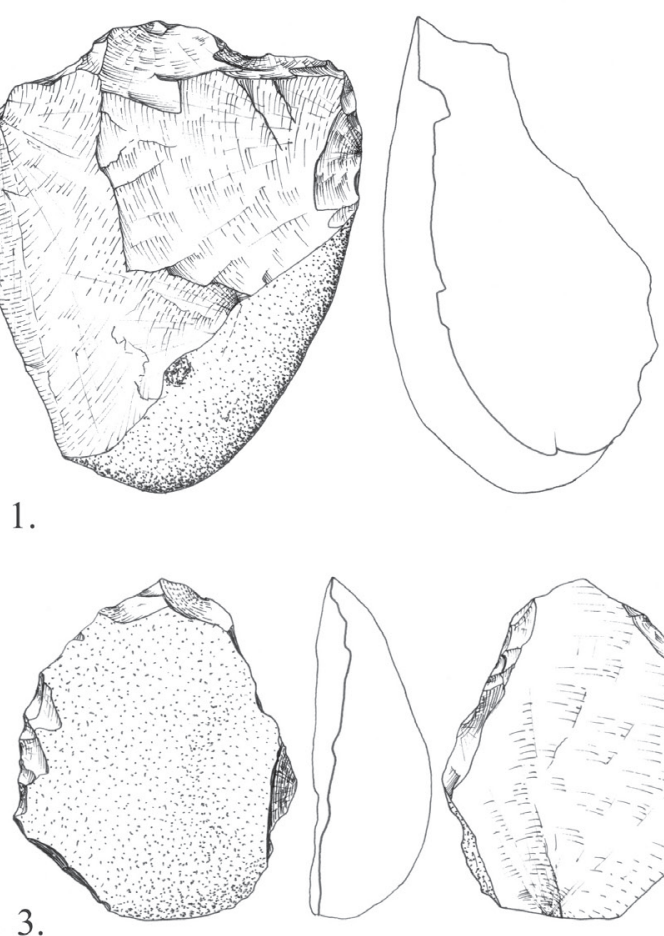

3.

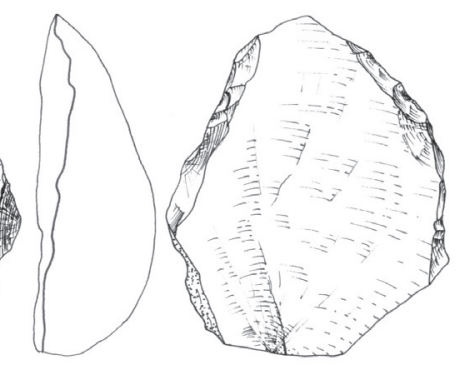

5.
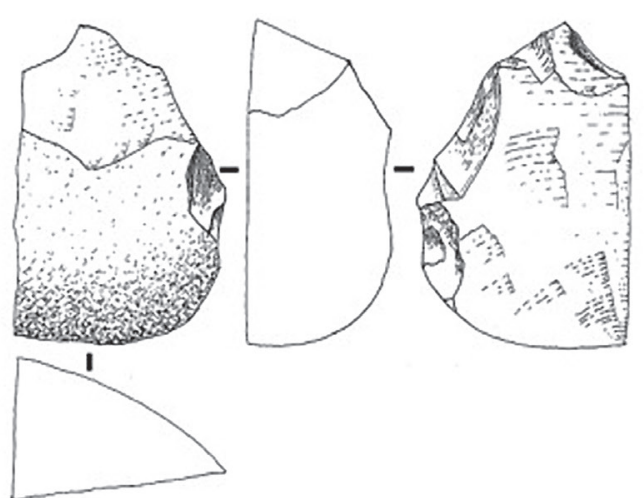

2.
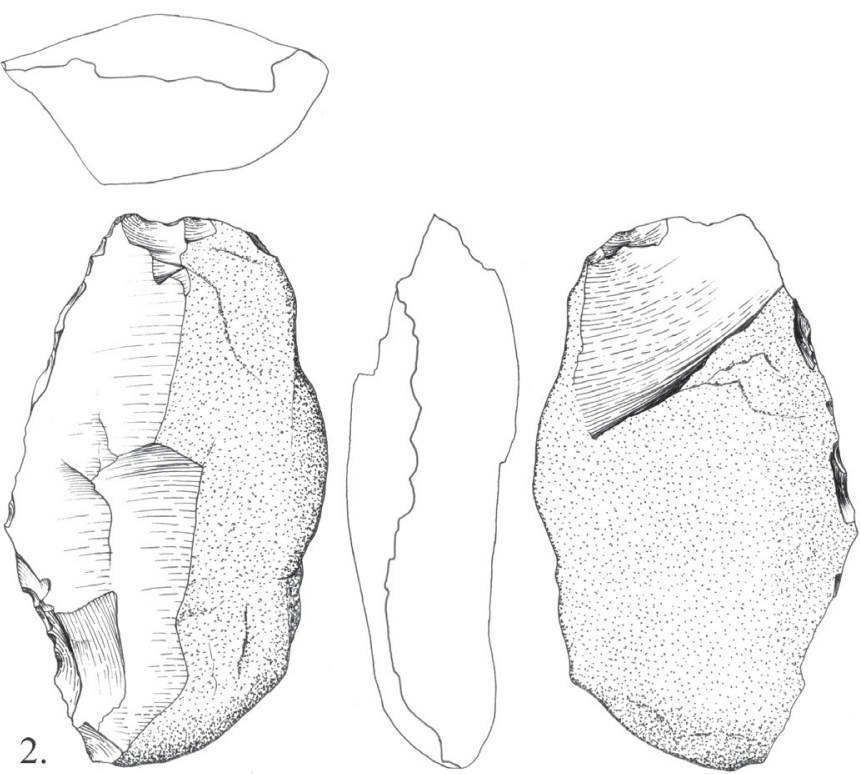

4.

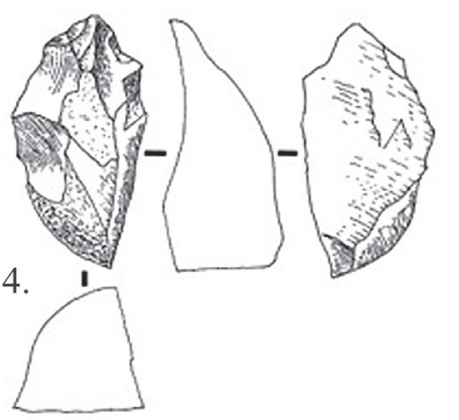

6.
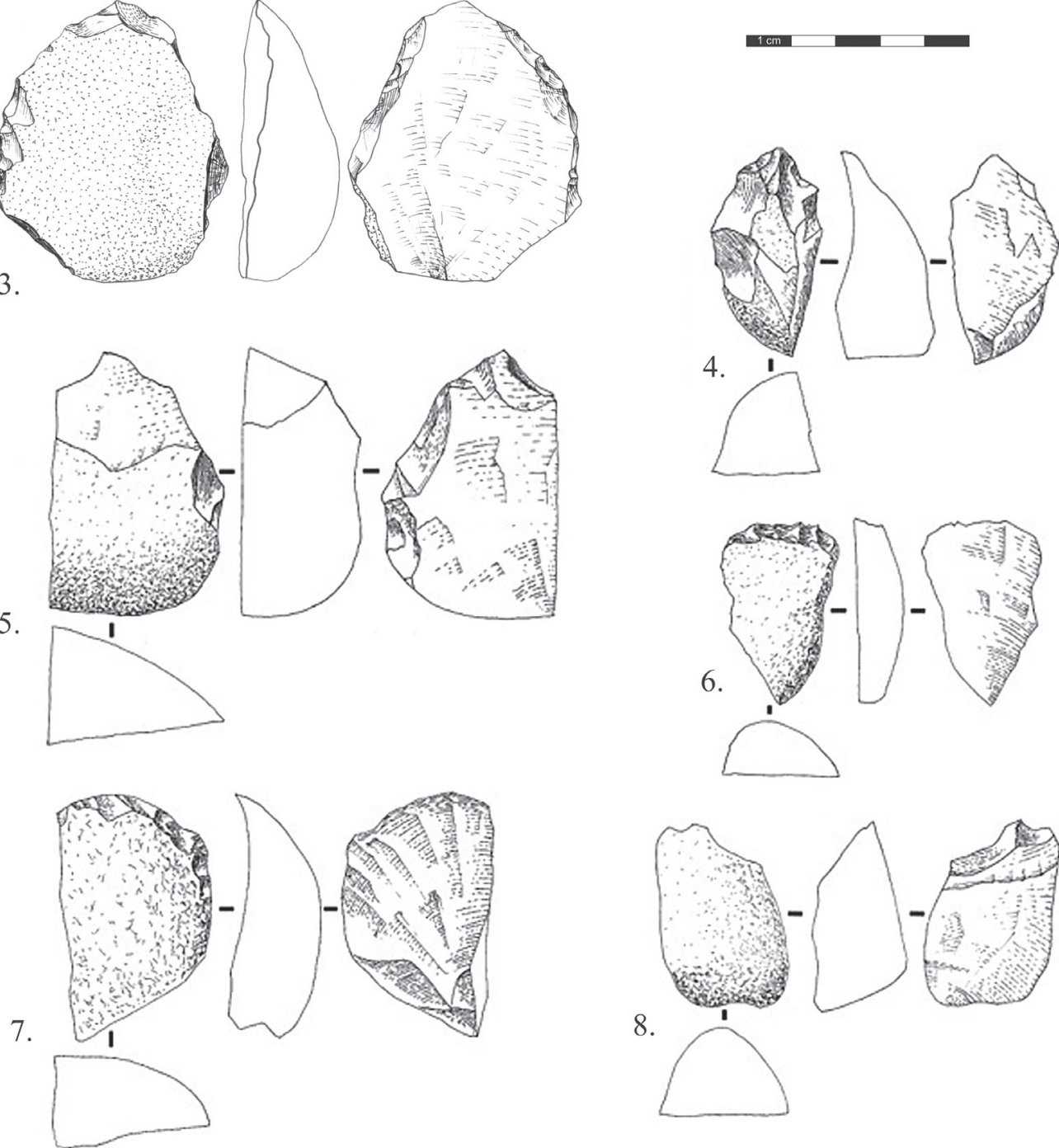

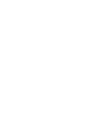




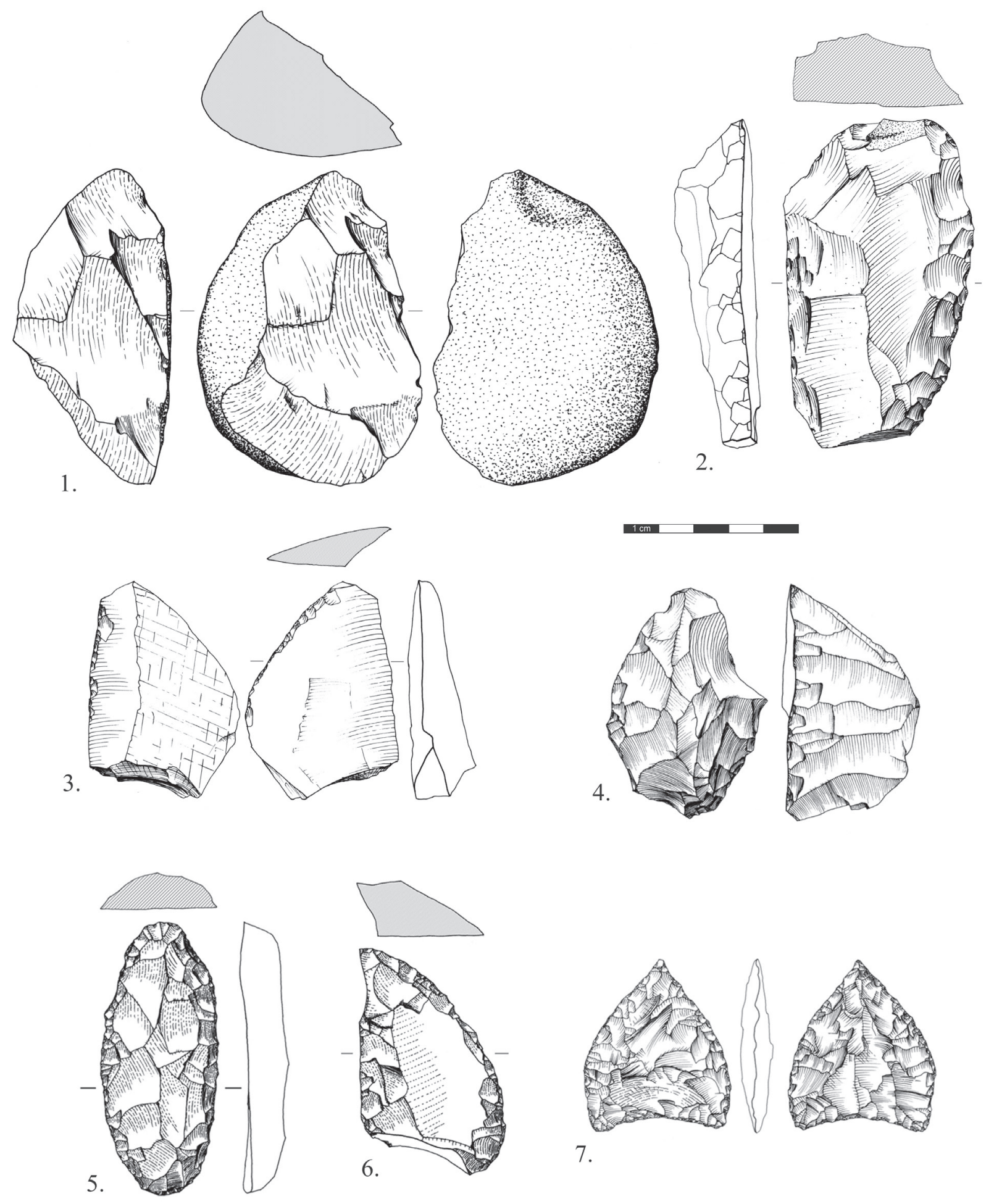

Figura 10 - Indústrias líticas da transição Pleistoceno-Holoceno e do Holoceno antigo na Serra da Capivara. 1-4 Boqueirão da Pedra Furada (Fase Serra Talhada); 5-7: Toca do Pica-Pau Fonte: Lourdeau (2010). 


\section{Vale da Pedra Furada}

Vale da Pedra Furada é um sítio a céu aberto perto de Pedra Furada. Encontrado em 1998, ele está sendo escavado novamente desde 2011 (BOËDA et al., 2014; FELICE, 2002). Dez níveis arqueológicos foram encontrados na sequência: dois na camada 2 , datada entre 9.000 e $7.000 \mathrm{AP}$ cal; quatro na camada 3, datada entre 16.500 e $14.500 \mathrm{AP}$ cal; um na camada 5, datada em 22.500 AP cal; três na camada 7, datada entre 26.500 e $23.000 \mathrm{cal}$ AP. As análises publicadas somente dão informação sobre as indústrias das camadas de idades pleistocênicas $(3,5,4)$, sobre um total de 294 artefatos. As matérias-primas usadas são seixos de quartzo e mais raramente de quartzito. Os suportes de instrumentos são produzidos sobre seixos ou lascas obtidas por debitagem bipolar sobre bigorna e, em proporções menores, debitagem unipolar. Os instrumentos produzidos são peças com bisel distal, rostres ${ }^{3}$, peças com gume convergente, bicos, denticulados ou raspadores (Figura 9, n. 4 -8). Estudos traceológicos atestam o trabalho da carne, da madeira, do osso e do couro, ou seja, comprovam atividades variadas (BOËDA et al., 2014). Os conjuntos diferenciam-se de um nível ao outro pelas proporções dos métodos e dos objetivos.

\section{Toca da Cerca do Elias}

Trata-se de um pequeno abrigo escavado em 2001 e 2002 (GUIDON; PESSIS; MARTIN, 2009). Pela distribuição das 6.424 peças líticas, quatro níveis arqueológicos foram definidos (LOURDEAU; PAGLI, 2014), o nível 3 tendo a única data absoluta do sítio: $12.060 \pm 170$ anos AP cal. O nível 1, que é o mais recente, por ter pouco material, é difícil de ser caracterizado. Os níveis 2, 3 e 4 apresentam uma indústria lítica bastante parecida, a partir de blocos e seixos de sílex, quartzito, arenito silicificado e quartzo. A produção é centrada sobre a obtenção de suportes alongados por debitagem laminar (Figura 11, n. 3) e por façonnage unifacial. Esses volumes alongados são suportes de vários tipos de instrumentos. As lâminas apresentam principalmente gumes lineares laterais opostos a dorsos (Figura 11, n. 1). As peças façonadas unifacialmente podem ser subdivididas em dois grupos do ponto de vista dos instrumentos confeccionados: suportes com gume apical e eventualmente outros gumes (peças Itaparica sensu LOURDEAU, 2014) (Figura 11, n. 2) e suportes com um único gume lateral (Figura 11, n. 4). Há, também, uma produção de lascas não alongada por debitagem em curtas sequências sem preparação do núcleo, as quais são suportes de instrumentos diversificados, a maioria possuindo uma única parte transformativa. Constatou-se, finalmente, a produção de instrumentos não alongados e espessos, principalmente sobre suportes naturais, com gumes retilíneos ou convexos.

\section{Toca da Baixa das Cabaceiras}

Esse sítio é um abrigo profundo e baixo, de plano semicircular escavado em 2001 (GUIDON, 2002; GUIDON; PESSIS; MARTIN, 2009). O material lítico encontrado compreende 3.076 peças lascadas de quartzo, quartzito, sílex e arenito silicificado, cuja distribuição horizontal permitiu definir dois níveis (LOURDEAU; PAGLI, 2014). O nível superior não é datado e apresentou pouco material, sendo, então, difícil a sua caracterização. O nível inferior é datado entre 8.800 e 9.880 anos AP cal. Os objetivos de lascamento da indústria são bastante variados: peças façonadas unifacialmente Itaparica (sensu LOURDEAU, 2014), geralmente em estado bastante esgotado (Figura 11, n. 6, 7), instrumentos de grande porte sobre seixos ou grandes lascas de tipo rostre (Figura 11, n. 5) e denticulados principalmente, instrumentos sobre lascas produzidas de debitagens com base na produção de curtas sequências de retiradas sem preparação do núcleo.

\section{Toca do Pica-Pau}

É um abrigo escavado em 2005. Na base da estratigrafia, observa-se uma camada com uma concentração importante de restos de carvão datada entre 8.200 e 9.600 anos AP cal (GUIDON; BUCO; IGNÁCIO, 2007; SANTOS, 2007; LOURDEAU, 2010). Um total de 1.569 vestígios lascados de arenito silicificado, quartzo e quartzito principalmente 
provêm dessa camada na base da sequência sedimentar, e os níveis superiores são quase estéreis do ponto de vista arqueológico. Nota-se a presença de peças façonadas unifacialmente Itaparica (Figura 10, n. 5), de instrumentos sobre lascas bastante variados, mas muitos deles apresentam um dorso oposto ao gume (Figura 10, n. 6), e de instrumentos sobre seixos, além de uma ponta de projetil de quartzo hialino (Figura 10, n. 7).
1.
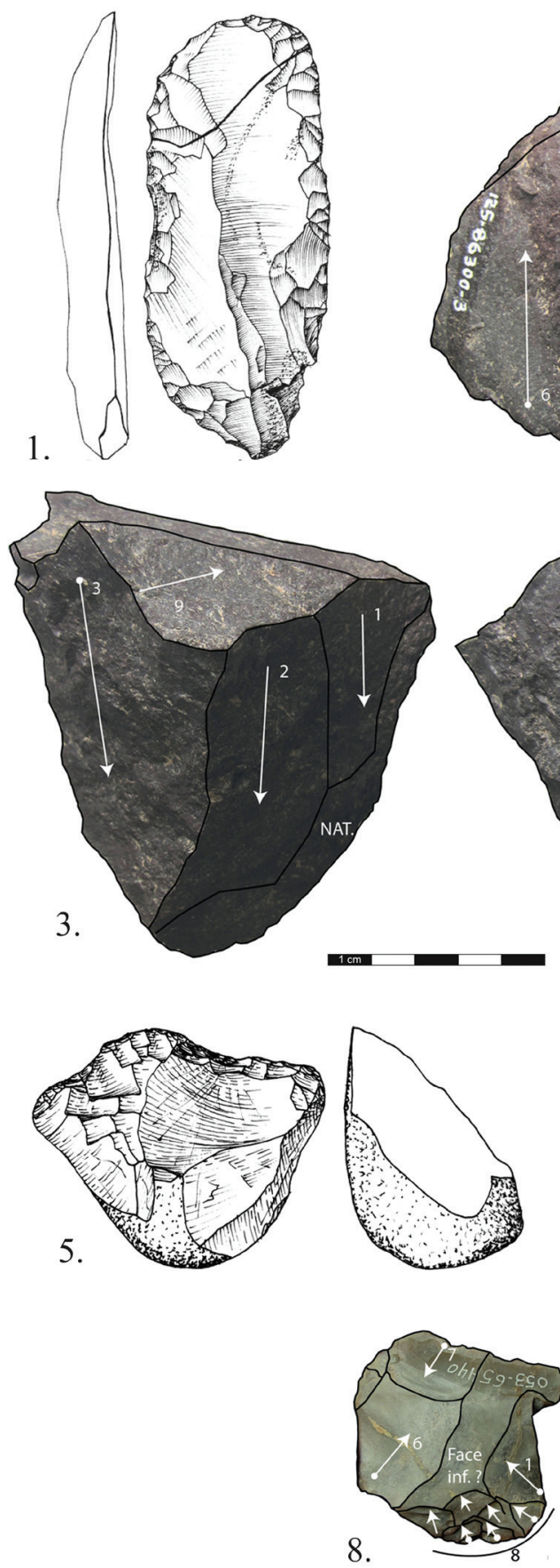

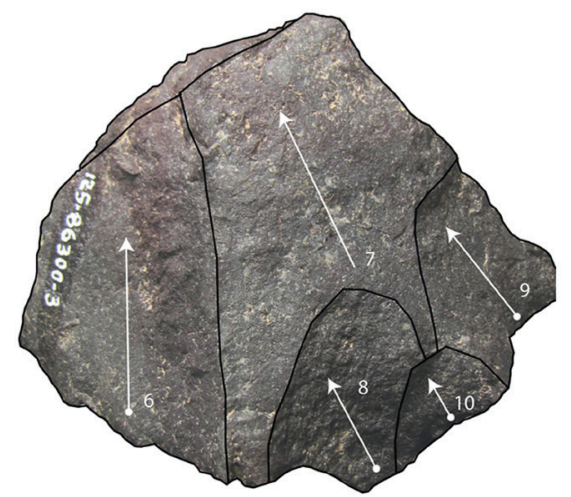

2.
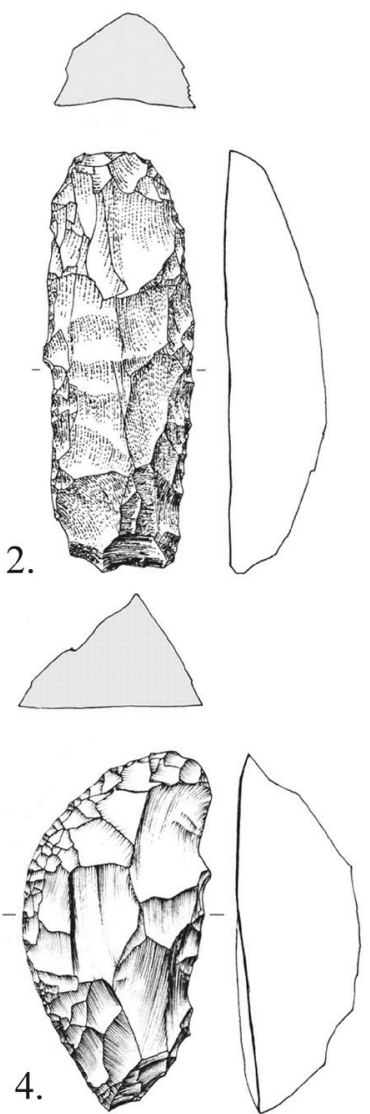

6.

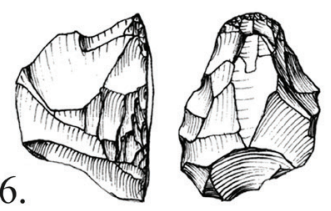

7.

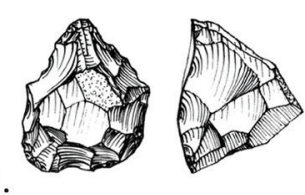

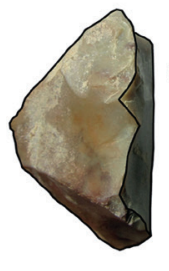

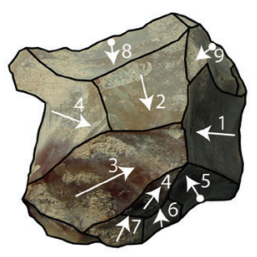

Figura 11 - Indústrias líticas da transição Pleistoceno-Holoceno e do Holoceno antigo na Serra da Capivara. 1-4 Toca da Cerca do Elias; 5-7: Toca da Baixa das Cabaceiras. Industrias líticas do Holoceno médio na Serra da Capivara: 8: Toca do Veado Fonte: Lourdeau e Pagli (2014). 


\section{Toca do Veado}

Esse abrigo foi escavado em 2001 (GUIDON, 2002; GUIDON; PESSIS; MARTIN, 2009). A distribuição vertical dos vestígios líticos mostra que a estratigrafia é formada por um único nível arqueológico, datado de $6.940 \pm 120$ anos AP cal (LOURDEAU; PAGLI, 2014). O material lítico compreende 841 peças lascadas de quartzito, quartzo, arenito silicificado e sílex. O conjunto da Toca do Veado é constituído de instrumentos diversificados, nos quais as principais tendências são as seguintes: instrumentos sobre lascas de pequeno tamanho, espessas, com gume denticulado principalmente; instrumentos sobre lascas largas, pouco espessas, com gume linear; instrumentos, sobre suportes naturais ou lascas, de grande tamanho e espessos com gumes denticuladas ou lineares, convergentes ou não (Figura 12, n. 1 - 6). Os núcleos demonstram a existência de uma debitagem de lasca similar àquela dos outros sítios, mas em alguns deles duas superfícies secantes não hierarquizadas são exploradas para produzir várias séries de retiradas secantes centrípetas (Figura 11, n. 8).

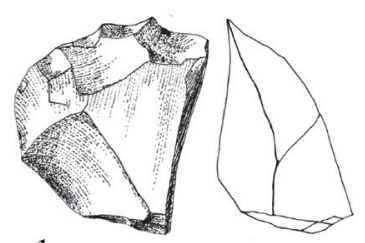

1.

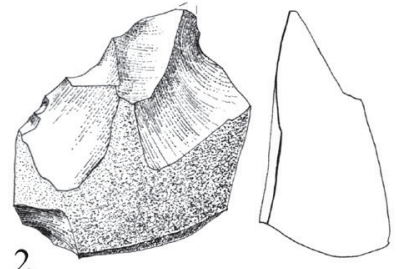

2.

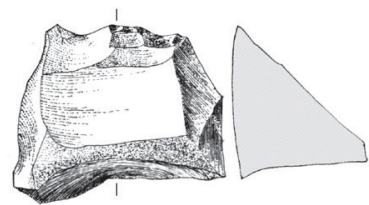

4.
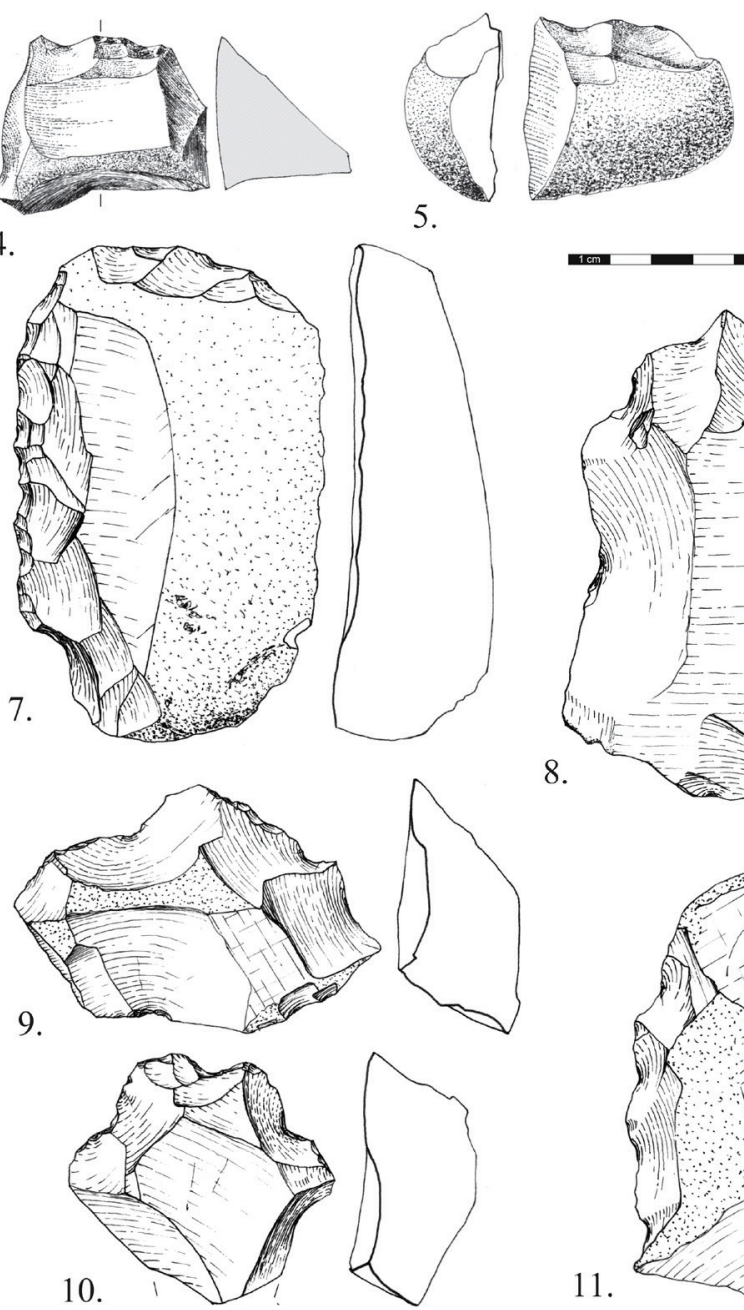

8.

11.

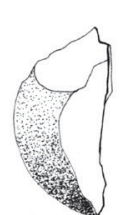

5.

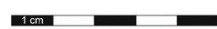

6

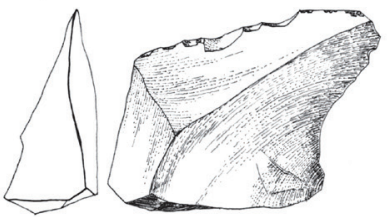

3.

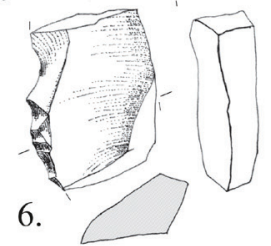

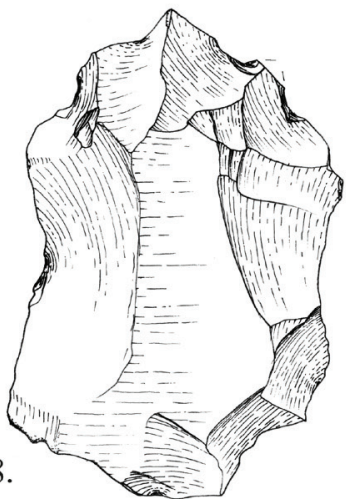
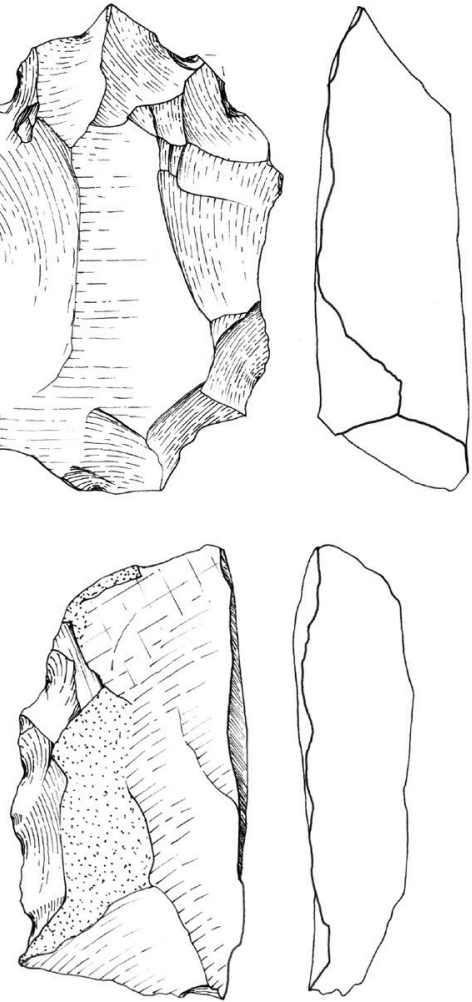

Figura 12 - Indústrias líticas do Holoceno médio na Serra da Capivara: 1-6: Toca do Veado; 7-11: Toca do Vento Fonte: Lourdeau e Pagli (2014). 


\section{Toca do Vento}

A Toca do Vento foi escavada em 1978, 1986 e 2004 (GUIDON, 1978b, 1981; GUIDON; PESSIS; MARTIN, 2009). A estratigrafia de referência, no setor 2, apresenta oito camadas (GUIDON; PESSIS; MARTIN, 2009; SANTOS, 2007). No total, 1.500 vestígios líticos foram encontrados em três conjuntos arqueológicos sucessivos: o superior nas camadas $1 \mathrm{e}$ 2, datado em $2.930 \pm 80$ anos AP cal, o intermediário na camada 4 e o inferior na camada 6, datado em $9.500 \pm 80$ anos AP cal (LOURDEAU; PAGLI, 2014). O conjunto inferior compõe-se de poucas peças líticas, o que dificulta uma caracterização técnica completa. O nível intermediário contém uma quantidade importante de instrumentos, a maioria sobre lascas, não façonadas. Um primeiro grupo inclui instrumentos compridos, com um dorso oposto a um gume lateral microdenticulado ou linear (Figura 12, n. 7, 11). Um segundo grupo é formado por instrumentos não alongados com gume macrodenticulado convexo (Figura 12, n. 9, 10). A presença de dois fragmentos de cerâmica na parte superior desse nível permite posicioná-lo no Holoceno recente. No nível superior, também encontrados instrumentos sobre lascas, alguns de dimensão muito grande. As partes transformativas denticuladas também são numerosas. No entanto, dois elementos novos são a convergência dos bordos e a modificação intensa de alguns suportes por façonnage uni-ou bifacial parcial (Figura 12, n. 8). Nos dois níveis mais recentes, as estruturas volumétricas dos núcleos sugerem possíveis fases de inicialização por lascas predeterminantes e uma concepção integrada podendo lembrar uma debitagem discoide.

\section{Aldeia da Queimada Nova e sítio Canabrava}

Trata-se de dois sítios lito-cerâmicos a céu aberto (PAIVA, 2011; VILHENA DE MORAES, 1976). A Aldeia da Queimada Nova (AQN) é datada em 1.900 anos AP cal, e o sítio Canabrava entre 700 e 300 anos AP cal. O material lítico é constituído de artefatos lascados e polidos. Os artefatos lascados são predominantes na $\mathrm{AQN}$ e em equilíbrio quantitativo com os artefatos polidos no sítio Canabrava. Quanto ao material lascado, um sistema de produção fundamentado sobre a exploração de superfícies naturais de blocos de quartzo e quartzito mediante curtas sequências unidirecionais parece ser atestado no sítio Canabrava. Nesse, instrumentos com partes transformativas latero-distais são predominantes. $\mathrm{Na} A Q N$ são atestados instrumentos sobre suportes não alongados e espessos, com gumes lineares ou denticulados. Um sistema de produção por façonnage é atestado nesses sítios. O material polido abrange machadinhas, machados semilunares, discos, bolas e tembetás.

\section{Proposta sintética de sequência tecnocultural na Serra da Capivara}

Com as análises do material lítico dessa dúzia de sítios arqueológicos podemos propor um novo esboço de sequência tecnocultural na Serra da Capivara. As principais características tecnológicas dessas indústrias ao longo do tempo podem ser apresentadas em um quadro sintético recapitulando os principais atributos em termos de modos de obtenção do volume dos instrumentos (por seleção de um suporte natural, ou por diferentes métodos de debitagem ou de façonnage) e em termos de tendências volumétricas e tecnofuncionais dos principais grupos de instrumentos (Figura 13).

Alguns aspectos dos sistemas técnicos encontram-se durante toda a sequência da região. Éo caso do uso de seixos como suportes de instrumentos, das debitagens bipolar sobre bigorna e em curtas séries unidirecionais para produção de lascas, e, em termos de objetivos, os instrumentos curtos com gume linear ou denticulado. Seria tentadora a ideia de ver a perduração destes elementos ao longo do tempo como um sinal de continuidade diacrônica nos sistemas técnicos; no entanto, vários deles são, na verdade, relativamente ubiquistas. Dessa forma, percebemos que o uso constante de seixos aparece, de fato, como uma tendência diacrônica forte da região.

Fora esses elementos de continuidade, existem mudanças técnicas notáveis ao longo da sequência. A partir do quadro geral atual, é possível distinguir quatro grandes períodos (Figura 13). 


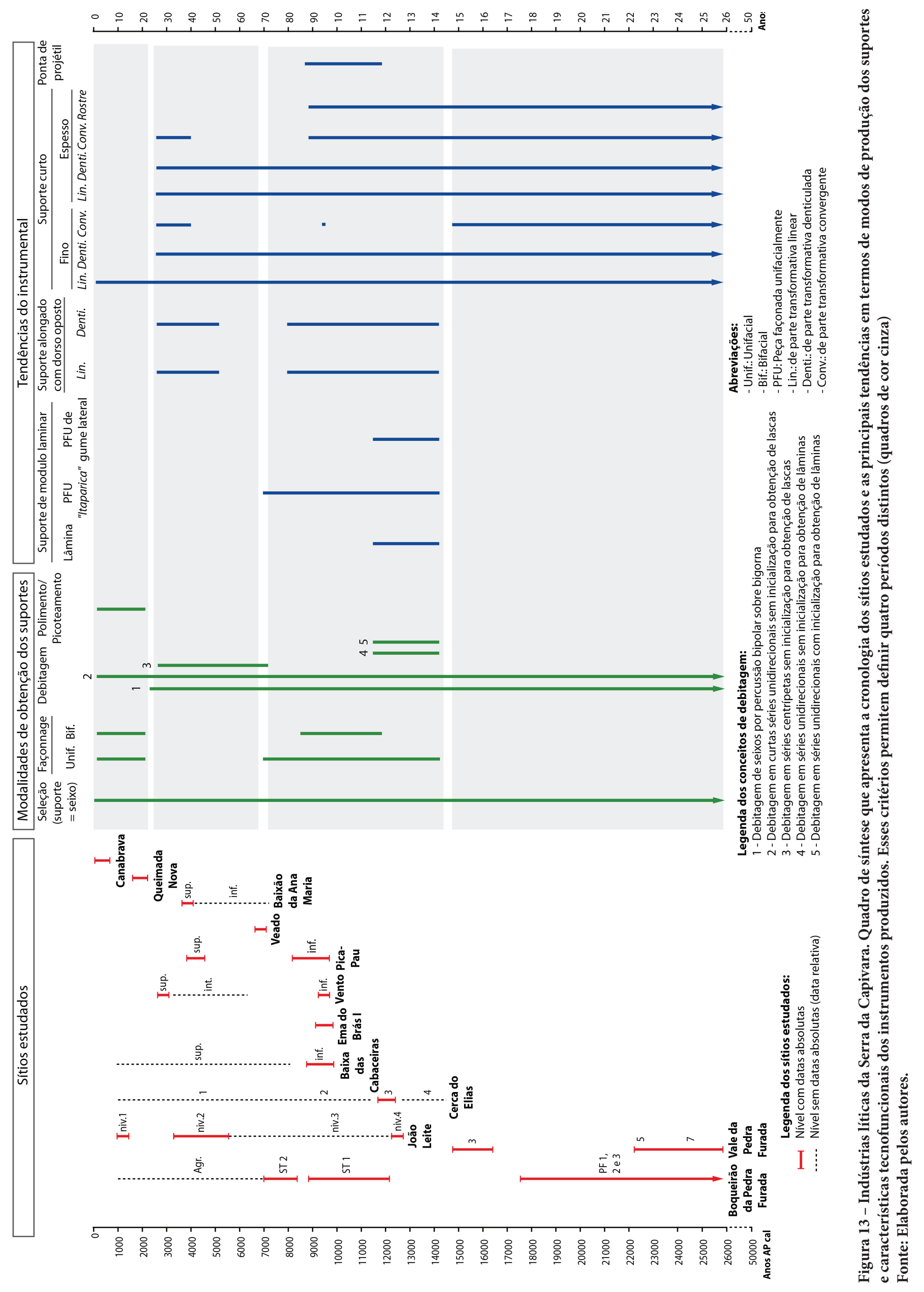




\section{O Pleistoceno final: primeiro povoamento da Serra da Capivara}

$\mathrm{Na}$ primeira fase de ocupação da região, entre aproximadamente 50.000 e 15.000 anos AP cal, as sequências estratigráficas da Toca do Boqueirão do Sítio da Pedra Furada e do Vale da Pedra Furada demonstram a existência de uma indústria lítica baseada exclusivamente na exploração de seixos de quartzo e de quartzito (BOËDA, 2014; BOËDA et al., 2014; PARENTI, 2001). Estes seixos são utilizados como suportes de instrumentos diversificados, com gumes retilíneos, denticulados, convergentes assim como rostres. O lascamento destes seixos é unifacial ou bifacial. Além destes suportes maciços, instrumentos sobre lascas são também confeccionados. Os suportes provêm de uma debitagem bipolar sobre bigorna e de uma debitagem por curtas séries unidirecionais. Os produtos são lascas corticais ou semicorticais, que foram retocadas para a instalação de diferentes partes transformativas lineares, denticuladas ou convergentes.

\section{A ocupação consolidada da transição Pleistoceno-Holoceno e do Holoceno antigo}

A partir de 13.000 e até aproximadamente 7.000 anos AP cal, a quantidade de ocupações humanas encontradas aumenta nitidamente, contemporaneamente a uma modificação tecnológica importante. Além dos seixos de quartzo e quartzito, começam a ser explorados seixos e blocos de sílex e arenito silicificado. O sistema técnico é embasado sobre uma complementaridade funcional entre dois objetivos principais: peças façonadas unifacialmente e instrumentos bastante normatizados sobre lascas.

As peças façonadas unifacialmente são de concepção "Itaparica", ou seja, suportes de instrumentos variados, com uma parte transformativa em uma extremidade, além de eventuais outras partes transformativas (LOURDEAU, 2010, 2014). Nas Tocas da Cerca do Elias e do João Leite, existem peças façonadas unifacialmente com uma parte transformativa lateral.

Os instrumentos sobre lascas têm seus suportes produzidos principalmente por uma debitagem por curtas séries unidirecionais, eventualmente repetidas na superfície de um mesmo núcleo. A debitagem bipolar sobre bigorna é também bem representada. Muitos desses instrumentos apresentam uma normalização volumétrica, sendo bastante alongados, com um gume lateral comprido, oposto a um dorso. Foram também produzidos instrumentos curtos sobre lasca ou seixo.

Encontram-se algumas raras pontas de projétil, que demonstram, ainda que de maneira muito pontual, atividades de façonnage bifacial.

Estas características convergem para associar essa indústria ao Tecnocomplexo Itaparica, que marca uma identidade tecnoculturaldo primeiro episódio de povoamento denso do Centro e Nordeste do Brasil (LOURDEAU, 2010, 2015, 2016).

As características específicas das produções líticas deste período não impedem uma variabilidade entre os conjuntos arqueológicos. Assim, somente na Toca da Cerca do Elias encontra-se uma debitagem laminar.

\section{Indústrias líticas do Holoceno médio: rupturas e inovações}

Existe uma nítida modificação das indústrias a partir de 7.000 anos AP cal. Este período poderia corresponder a uma reorganização da ocupação da região, concomitantemente a uma diminuição do número de sítios datados na faixa de 7.000 a 2.000 anos AP cal.

A ruptura técnica desse período é visível pelo abandono completo do façonnage unifacial e por uma ausência aparente da normatização volumétrica dos objetivos de lascamento. Os instrumentos são produzidos sobre lascas de tamanho e morfologia variada, a partir das mesmas matérias-primas do período anterior.

Nas Tocas do Vento e do Baixão da Ana Maria, na segunda metade deste período, ressurgem instrumentos normatizados alongados, com dorso oposto ao gume, e aparecem de maneira recorrente, no nível superior, peças convergentes e denticuladas. A evolução dos sistemas de debitagem de lascas constitui outra especificidade das indústrias do Holoceno médio. Novos métodos aparecem, como a debitagem centrípeta, associada a novos 
tipos de produtos, que servem de suportes para os instrumentos. Esta debitagem centrípeta parece evoluir, em alguns sítios em uma possível debitagem de concepção Discoide (BOËDA, 1995), como é possivelmente o caso na Toca do Vento.

\section{Indústrias líticas dos grupos ceramistas do Holoceno recente}

As produções líticas dos dois últimos milênios são ainda muito pouco conhecidas do ponto de vista tecnológico. Este período é associado ao desenvolvimento de novas técnicas de modificação da pedra, o polimento e o picoteamento (técnicas já foram pontualmente utilizadas no período anterior). Em relação ao lascamento, existem debitagens de lascas, sobre os quais são produzidos instrumentos, não bem definidos ainda. Parecem surgir de novo os façonnages unifacial e bifacial, para produzir instrumentos de concepções talvez diferentes daqueles do Holoceno antigo.

Agradecimentos: Os autores agradecem à Fundação Museu do Homem Americano (FUMDHAM), dirigida por Niède Guidon, e o Instituto Nacional de Arqueologia, Paleontologia e Ambiente do Semiárido (INAPAS), coordenado por Anne-Marie Pessis, por terem disponibilizado o material estudado. Somos gratos a Eric Boëda por ter autorizado a publicação das figuras de Vale da Pedra Furada (Figura 9, n. 4 -8). A análise dos sítios Toca da Ema do Sítio do Brás I e Toca do Baixão da Ana Maria foi realizada por Marina Pagli no âmbito de um Pós-doutorado júnior do CNPq no INAPAS.

\section{Notas}

1 As ocupações antigas do sítio da Pedra Furada são entre as mais antigas do continente americano, remontando até ao redor de 50.000 anos atrás (PARENTI, 2001). Sendo bem mais antigas que a data geralmente aceita para o primeiro povoamento do continente, elas foram, e ainda são, muito debatidas, entre outros, por Meltzer, Adovasio e Dillehay (1994). Devido ao fato de o enfoque específico deste artigo não ser essa questão das ocupações antigas, não retomaremos em detalhe essas discussões. No entanto, diante de evidencias cada vez mais consistentes de presença humana na Serra da Capivara durante o Pleistoceno final, em Pedra Furada, mas também no Sítio do Meio (BOËDA et al., 2013), no Vale da Pedra Furada (BOËDA et al., 2014) e na Toca da Tira-Peia (LAHAYE et al., 2013; BOËDA et al., 2013), é imprescindível levarmos em consideração essas ocupações pleistocênicas para o entendimento da sequência tecnocultural da Serra da Capivara.

2 Para uma síntese das datas, da localização dos sítios e a lista das publicações referentes a essas pesquisas, remetese para Lourdeau e Pagli (2014).

$3 \mathrm{O}$ rostre define-se por "[...] uma saliência não convergente que sai da linha geral do instrumento. Essa saliência é variável, com delineação retangular, convexa ou microdenticulada etc.”. (BOËDA et al., 2014).

\section{Referências}

BOËDA, E. Caractéristiques techniques des chaînes opératoires lithiques des niveaux micoquiens de Külna (Tchécoslovaquie). Paléo Supplément, n. 1, p. 52-72, 1995.

Deve-se recear as indústrias sobre seixo? Análise comparativa entre as indústrias pleistocênicas da Ásia Oriental e da América do Sul. In: LOURDEAU, A.; VIANA, S. A.; RODET, J. (Ed.). Indústrias líticas na América do Sul: abordagens teóricas e metodológicas. Recife: Editora UFPE, 2014. p. 11-36.

.; LOURDEAU, A.; LAHAYE, C.; FELICE, G.; VIANA, S.; CLEMENTE-CONTE, I.; PINO, M.; FONTUGNE, M.; HOELTZ, S.; GUIDON, N. The Late-Pleistocene Industries of Piauí, Brazil: New Data. In: GRAF, K.; KETRON, C.; WATERS, M. (Ed.). Paleoamerican Odyssey. 1. ed. Texas: A\&M University, College Station, 2013. p. 445-465.

; CLEMENTE-CONTE, I.; FONTUGNE, M.; LAHAYE, C.; PINO, M.; FELICE, G.; GUIDON, N.; HOELTZ, S.; LOURDEAU, A.; PAGLI, M.; PESSIS, A. M.; VIANA, S.; DA COSTA, A.; DOUVILLE, É.. A new late Pleistocene archaeological sequence in South America: the Vale da Pedra Furada (Piauí, Brazil). Antiquity, v. 88, n. 341, p. 927-941, 2014.

FELICE, G. A controvérsia sobre o sítio arqueológico Toca do Boqueirão da Pedra Furada, Piauí - Brasil. Fumdhamentos, v. 2, p. 143-178, 2002. 
GUIDON, N. O Páleo-índio em Piauí. Anuário de Divulgação Científica - UCG, Goiânia, v. 5, p. 55-61, 1978a.

. Missão arqueológica no sudeste do Piauí, Brasil. Relatório final. Revista do Museu Paulista USP, v. 25, p. 109-128, 1978 b.

Las unidades culturales de São Raimundo Nonato, sudeste del estado de Piauí. In: BRYAN, A. L. (Ed.). X Congesso de la Unión Internacional de Ciencias Prehistóricas y Protohistóricas, Comisión XII: El Poblamiento de América. UISPP, Mexico, 1981. p. 101-111.

.Unidades culturais da tradição Nordeste na área arqueológica de São Raimundo Nonato. Revista do Museu Paulista - USP, v. 30, p. 115-147, 1985.

A sequência cultural da área de São Raimundo Nonato, Piauí. Clio - Série arqueológica - UFPE, v. 3, n. 8, p. 137-144, 1986.

Peintures préhistoriques du Brésil: l’art rupestre du Piauí. Paris: Editions Recherche sur les Civilisations, 1991.

Contribuição ao estudo da paleogeografia da área do Parque Nacional Serra da Capivara. Clio - Série arqueológica - UFPE, v. 3, n. 8, p. 137-144, 2002.

; BUCO, C.; IGNÁCIO, E. Escavações em três abrigos da Serra Branca. Fumdhamentos, v. 6, p. 52-73, 2007.

.; PESSIS, A. M.; MARTIN, G. Pesquisas arqueológicas na região do Parque Nacional Serra da Capivara (Piauí - 1998-2008). Fumdhamentos, v. 8, p. 1-61, 2009.

LAHAYE, C.; HERNANDEZ, M.; BOEDA, É.; FELICE, G.; GUIDON, N.; HOELTZ, S.; LOURDEAU, A.; PAGLI, M.; PESSIS, A. M.; RASSE, M.; VIANA, S. Human occupation in South America by 20,000 BC: the Toca da Tira Peia site, Piauí, Brazil. Journal of Archaeological Science, v. 40, n. 6, p. 2840-2847, 2013.
LOURDEAU, A. Le technocomplexe Itaparica: définition techno-fonctionnelle des industries à pièces façonnées unifacialement à une face plane dans le centre et le nord-est du Brésil pendant la transition Pléistocène-Holocène et l'Holocène ancien. 2010. $477 \mathrm{f}$. Thèse (Doctorat Antrophologie de préhistoire) - Université Paris Ouest Nanterre La Défense, Nanterre, 2010. Disponível em: <https:// bdr.u-paris10.fr/theses/internet/2010PA100190. pdf $>$. Acesso em: 1 abr. 2016.

Considerações metodológicas sobre a identificação de conjuntos culturais a partir das indústrias líticas no Centro e Nordeste do Brasil. In: LOURDEAU, A.; VIANA, S.; RODET, J. (Ed.). Indústrias líticas na América do Sul: abordagens teóricas e metodológicas. Recife: Editora UFPE, 2013. p. 65-90.

As peças façonadas unifacialmente do tecnocomplexo Itaparica (centro e nordeste do Brasil): conceito e variabilidade. In: FARIAS, M.; (Ed.). Peuplement de l'Amérique du sud: l'apport de la technologie lithique. Prigonrieux: Archéo-éditons, 2014. p. 97-122.

. Lithic Technology and Prehistoric Settlement in Central and Northeast Brazil: Definition and Spatial Distribution of the Itaparica Technocomplex. Paleoamerica, v. 1, n. 1, p. 52-67, 2015.

. Industries lithiques du centre et du nord-est du Brésil pendant la transition Pléistocène-Holocène et l'Holocène ancien: la question du Technocomplexe Itaparica. L'Anthropologie, v. 120, n. 1, p. 1-34, 2016.

; PAGLI, M. Indústrias líticas pré-históricas na região da Serra da Capivara. In: PESSIS, A. M.; MARTIN, G.; GUIDON, N. (Ed.). Os biomas e as sociedades humanas na pré-história da região do Parque Nacional Serra da Capivara. São Paulo: A\&A Comunicação, 2014. v. II B. p. 551-635.

LUCAS, L. Mudanças técnicas da transição Pleistoceno-Holoceno ao Holoceno médio no interior do Nordeste: indústrias líticas da sequência arqueológica da Toca do João Leite - PI. 2014. 160 f. Dissertação (Mestrado em Arqueologia) - Programa de Pós-Graduação em Arqueologia, 
Universidade Federal de Pernambuco, Recife, 2014. Disponível em: <http://repositorio.ufpe.br/ handle/123456789/17181>. Acesso em: 1 abr. 2016.

Mudanças técnicas do Holoceno inicial e médio: o caso da Toca do João Leite - PI. Habitus, v. 13, n. 2, p. 41-56, 2016.

MELTZER, D.; ADOVASIO, J. M.; DILLEHAY, T. D. On a Pleistocene human occupation at Pedra Furada, Brazil. Antiquity, v. 68, p. 695-714, 1994.

PARENTI, F. M. Le gisement Quaternaire de la Toca do Boqueirão da Pedra Furada (Piauí, Brésil): Stratigraphie, chronologie, evolution culturelle. 1993. 312 f. Thèse (Doctorat Archéologie) - École des Hautes Études en Sciences Sociales, Paris, 1993.

\section{Le gisement quaternaire de Pedra}

Furada (Piauí, Brésil). Stratigraphie, chronologie, évolution culturelle. Paris: Editions Recherche sur les Civilisations, 2001.

PAIVA, B. Tecnologia lítica dos grupos ceramistas da área arqueológica de São Raimundo - PI: um estudo de caso aplicado ao sítio Canabrava. 2011. 219 f. Dissertação (Mestrado em Arqueologia) - Programa de Pós-Graduação em Arqueologia, Universidade Federal de Pernambuco, Recife, 2011. Disponível em: <http://repositorio.ufpe. br:8080/xmlui/bitstream/handle/123456789/466/ arquivo1369_1.pdf? sequence $=1$ \&isAllowed $=y>$. Acesso em: 1 abr. 2016.

PESSIS, A. M. Imagens da pré-história, Parque Nacional Serra da Capivara. São Paulo: A\&A Comunicação, 2003.

ROCHA, J. S. A indústria lítica em três sítios arqueológicos do Piauí (Nota Prévia). Clio - Série arqueológica - UFPE, v. 1, n. 6, p. 113-125, 1984.

SANTOS, J. O Quaternário do Parque Nacional Serra da Capivara e entorno, Piauí, Brasil: morfoestratigrafia, sedimentologia, geocronologia e paleoambientes. 2007. $171 \mathrm{f}$. Tese (Doutorado em Arqueologia) - Universidade Federal de Pernambuco, Recife, 2007. Disponível em: $<$ http://repositorio.ufpe. br/handle/123456789/6387>. Acesso em: 1 abr. 2016.

SANTOS, M. G. C. M.; ROCHA, J. S. Relatório da análise tipológica do material lítico dos sítios arqueológicos do Sudeste do Piauí. Cadernos de pesquisa (Série antropologia II) - UFPI, v. 3, p. 103-200, 1982.

VILHENA DE MORAES, Á. A indústria lítica do sítio Aldeia da Queimada Nova, município de São Raimundo Nonato, Piauí. Revista do Museu Paulista - USP, v. 23, p. 21-40, 1976. 